\title{
The Punishment of Dixie Shanahan: Is There Justice for Battered Women Who Kill?
}

\author{
Leigh Goodmark*
}

\section{INTRODUCTION}

Dixie Schrieber and Scott Shanahan began dating in 1983. On May 10, 2004, Dixie Schrieber Shanahan was sentenced to fifty years of imprisonment for the murder of Scott Shanahan. In between, there was a marriage, children - and years of horrendous abuse. During the nineteen years that Dixie and Scott Shanahan were together, Scott blackened Dixie's eyes, bruised her, threatened her, dragged her by her hair, pointed guns at her, tied her up and left her for days in the basement, called her vile names, degraded her in front of friends, and generally made her life a living hell. On August 30, 2002, believing that her life and the life of her unborn child were in danger after days of beatings, threats, and the promise, "This day is not over yet. I will kill you," Dixie Shanahan shot her husband while he lay in bed. After less than one day of deliberation, a jury found Dixie Shanahan guilty of second-degree murder. Judge Charles L. Smith III sentenced Dixie Shanahan to fifty years in prison. ${ }^{1}$

The community of Defiance, Iowa, divided sharply around the prosecution of Dixie Shanahan. During the trial, both prosecution and defense witnesses agreed that Scott Shanahan was an extremely violent man who brutally abused his wife for years. But members of the community debated whether Dixie Shanahan was justified in killing her abuser. Some characterized Dixie Shanahan's actions as a final, desperate attempt to save herself and her baby; others conceded the severity of the abuse she endured over the years but maintained that she had no right to take Scott Shanahan's life. ${ }^{2}$

\footnotetext{
* Assistant Professor, University of Baltimore School of Law. My thanks to Steven Grossman, Jane Murphy, and Doug Nierle for their assistance in shaping this Article, and to Jennifer Salyers, my incredible research assistant.

1. See infra Part II (discussing facts in Dixie Shanahan's case).

2. See Shanahan Punished by Husband and State, Letters to the Editor, Des MoINES REG., May 5, 2004, at 14A (including letters both for and against Dixie Shanahan); Mike Tidman, Letter to the Editor, All Is Well with the Justice System, Des MoINES REG., June 8, 2004, at 8A ("Sounds like
} 
Accept, for the sake of argument, that Dixie Shanahan was guilty of second-degree murder in the shooting death of her husband, Scott-that the prosecution proved beyond a reasonable doubt that she shot her husband and that that shooting was not justified. ${ }^{3}$ Was the punishment that Dixie Shanahan received in this case just? Fifty years of imprisonment, with a requirement that she serve thirty-five years before becoming eligible for parole. Nineteen years of abuse followed by, essentially, a lifetime in jail. Members of the jury later asked the governor to reduce the sentence; ${ }^{4}$ one juror had assumed that Shanahan would be sentenced to twenty-five years and serve, at most, eight years. ${ }^{5}$

Criminal punishment in America has been justified by philosophers employing a number of theories. Chief among these are retribution, deterrence, rehabilitation, and incapacitation. ${ }^{6}$ Each of these could potentially serve as a rationale for punishing Dixie Shanahan. Closer examination of her case, and the cases of other battered women who kill, however, raises the question of whether these rationales make sense in the context of these cases. Are the punishments meted out to these women just? ${ }^{7}$ This Article approaches that question by discussing each

murder to me. And now she's going to pay a murderer's penalty. All's well with the justice system."); Sherie Vermeer, Letter to the Editor, Have the Courage to Pardon Shanahan, DES MOINES REG., June 8, 2004, at 8A ("If you have not been in her position, you cannot know the feeling of helplessness that would drive you to protect yourself and your children by such desperate means."); see also John Ferak, Verdict Leaves Kids in Limbo, OMAHA WORLD-HERALD, May 1, 2004, at 1B (quoting Defiance residents regarding the Shanahan verdict).

3. Shanahan never denied that she shot her husband but did argue that her actions were justified. Transcript of Trial at 812-23, State v. Shanahan, No. FECR006475 (Iowa Dist. Ct. Shelby County Apr. 30, 2004). The jury rejected that argument, apparently because Shanahan followed her husband into the bedroom and shot him in the back while he was lying in bed, during a lull in the abuse. From their verdict, it seems that jurors did not believe that Shanahan was in imminent danger and had no other option but to kill in self-defense. Dixie Shanahan's conviction for second-degree murder was affirmed by the Supreme Court of Iowa in April 2006. State v. Shanahan, 712 N.W.2d 121, 144 (Iowa 2006). For a discussion of the difficulties battered women who kill face in making self-defense cases, see generally Kit Kinports, So Much Activity, So Little Change: A Reply to the Critics of Battered Women's Self-Defense, 23 St. LouIS U. PuB. L. REV. 155 (2004).

4. Staci Hupp, Chances of Being Pardoned Slim for Shanahan, Des MoINES Reg., May 29, 2004, at 1A. In January 2007, Governor Tom Vilsack commuted Shanahan's sentence, decreasing the mandatory minimum time that she must serve before becoming eligible for parole from thirtyfive years to ten. John Ferak, Sentence Commuted for Woman Who Kept Husband's Body in Bedroom, OMAHA WORLD-HERALD, Jan. 6, 2007, available at 2007 WLNR 254151.

5. Staci Hupp, 'It May Be Legal, But It Is Wrong', Des MoINES REG., May 11, 2004, at 1A.

6. Steven Grossman, Proportionality in Non-Capital Sentencing: The Supreme Court's Tortured Approach to Cruel and Unusual Punishment, 84 KY. L.J. 107, 162-63 (1995-1996).

7. Abbe Smith has remarked on the speed with which advocates for battered women decry the convictions of battered women who kill but show little interest in defending other victims accused of crimes (such as Aileen Wuornos, who killed several men after years of abuse as a prostitute). Abbe Smith, The "Monster" in All of Us: When Victims Become Perpetrators, 38 Suffolk U. L. Rev. 367, 382-84 (2005). While this Article falls squarely within that critique, it does so mindfully. Similar arguments about the justice of individual punishments and the failure to consider the context 
of the rationales for criminal punishment in turn and applying them to the case of Dixie Shanahan. Would punishing Dixie Shanahan deter future crime - either by her or by other battered women? Does her punishment serve some retributive function? Will Dixie Shanahan be rehabilitated as a result of her punishment? Is Dixie Shanahan's incapacitation for thirty-five years just? Examination of each of these rationales reveals that only one, retributivism, provides sufficient justification for punishing Dixie Shanahan and other battered women who kill, and only to the extent that they receive their just deserts-punishments proportionate to the crime, considering the entire context for the crime. Because the fifty-year sentence she received is not a just desert, the punishment actually imposed on Dixie Shanahan was not just.

Like many battered women who kill, Dixie Shanahan received an unjust sentence. In Dixie Shanahan's case, that injustice was largely a function of mandatory minimum sentences. Though he agreed with the verdict, denying a defense motion for a new trial, Judge Smith was frustrated by his lack of sentencing options. At sentencing, Judge Smith told Dixie Shanahan that because of mandatory minimum sentences enacted by the Iowa Legislature, he did not have the ability to impose a lighter sentence (like probation) or suspend her sentence-punishments he believed more appropriate. ${ }^{8}$ He stated, "This matter is a tragedy in every sense. You've suffered abuse, one person is dead and now you're looking at almost a lifetime of jail. None of that is necessary." "While the fifty-year sentence was legal, according to Judge Smith it was also

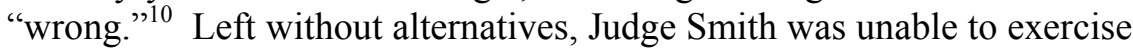
any discretion in sentencing, despite the years of abuse Dixie Shanahan suffered and despite his belief that a long period of incarceration was inappropriate.

But what accounts for the injustice done to battered women who kill in jurisdictions without such stringent sentencing requirements? In those cases, judicial skepticism concerning evidence of abuse and (unfounded) fears of an epidemic of homicides may drive judges to impose unjust sentences. Judges either refuse to hear evidence about the battering these

for their crimes in imposing punishment could be made about any number of offenders involved with the criminal system; as Smith notes, "[I]t is the rare serious perpetrator who was not also a victim. ... . [I]t is the rare perpetrator who has not also suffered." Id. at 369. Smith further argues that context is essential for understanding not only the victim's actions, but also her abuser's, asserting that " $[\mathrm{t}]$ he same social and political conditions that give rise to violence against women give rise to violence by men." Id. at 392.

8. Transcript of Sentencing at 5-6, Shanahan, No. FECR006475.

9. Id. at $9-10$.

10. Id. at $8-9$. 
women have suffered or hear that evidence but refuse to consider the crime in the context of the abuse. Either way, crucial information that would lead to the imposition of a "just desert" is excluded from sentencing decisions. Finally, concerns about the impact of failing to impose stringent sentences on women who kill their abusive partners drive judges to mete out unjust sentences.

For Dixie Shanahan, as for other battered women who kill, there is no justice. Context - examining the lives of Dixie Shanahan and other women like her, and asking how they come to the point where killing their batterers seems to be their only option - is crucial to establish why most traditional rationales for criminal punishment are inadequate in these cases. This Article begins with that context.

\section{THE LIFE OF DIXIE SHANAHAN}

Dixie Schrieber was born in Muscatine, Iowa, in $1967 .{ }^{11}$ In 1976, Schrieber's mother married a man named Frank Street, who sexually abused Dixie and her sisters for years until Dixie threatened to report the abuse to police. ${ }^{12}$ In 1984, the same year that Dixie threatened to report her stepfather, she moved to Defiance, Iowa, to live with Al and Beverly Feser, the parents of Scott Shanahan, whom she had begun dating in 1983. ${ }^{13}$ Both of the Fesers had physical infirmities. Dixie cared for them and developed close, loving relationships with them; in fact, Dixie said that Beverly was more like a mother to her than her own mother. ${ }^{14}$

From the beginning of their relationship, Scott verbally and physically abused Dixie. Although Dixie described this abuse as minor compared to what she would later experience, in those early years Scott was already beating her so severely that she was bruised. ${ }^{15}$ But Dixie was not his only victim; Scott also physically abused his mother, Beverly, who had a heart condition and had undergone triple bypass surgery. ${ }^{16}$ Dixie described Scott's temper as unpredictable and likely to

11. Transcript of Trial, supra note 3, at 437-38.

12. Id. at 438-39. Battered women frequently come from homes where they have been physically or sexually abused as children. See LENORE E. WALKER, THE BATTERED WOMAN SYNDROME 8 (1984) ("[E]vents reported by the [battered] women . . . included early and repeated sexual molestation and assault, [and] high levels of violence by members in their childhood families ....").

13. Transcript of Trial, supra note 3 , at $440,442$.

14. Id. at $440-42$.

15. Id. at 443-44. Battering often increases in severity over time. AM. PSYCHOLOGICAL AsS'N PRESIDENTIAL TASK ForCE ON ViOLENCE \& THE FAMILY, ViolenCE AND THE FAMILY 6 (1996).

16. Transcript of Trial, supra note 3 , at 441-43. 
explode over trivial matters, such as the lawnmower failing to start. ${ }^{17}$ In 1986, Scott beat Dixie for visiting her family, who she had not seen since she moved to the Fesers' home in $1984 .^{18}$

In 1988, Scott's mother developed pneumonia after attending her brother-in-law's funeral; Scott reacted by beating Beverly so severely that she was bruised from head to toe. ${ }^{19}$ Around this time, Beverly extracted a promise from Dixie that if anything ever happened to her, Dixie would take care of Scott-a promise that Dixie took seriously given the closeness of her relationship with Beverly. ${ }^{20}$ During that same period of time, Dixie estimates that Scott was beating both her and Beverly about twice a week. ${ }^{21}$ Each time Scott experienced adversityhis mother's sickness, the death of his grandfather in 1993 - the beatings worsened. ${ }^{22}$ In 1994, when Beverly died, Scott "[w]ent off the wall . . beating [Dixie] more frequently about anything." 23

In 1995, Dixie Schrieber married Scott Shanahan. ${ }^{24}$ In 1996, their son Zachary was born, ${ }^{25}$ followed by Ashley in $1998 .{ }^{26}$ Scott was unhappy about the first pregnancy, worrying that they had no experience caring for a child and that Dixie, the sole breadwinner, would have to stop working. ${ }^{27}$ During Dixie's second pregnancy, after Dixie refused to have an abortion, Scott beat her in the stomach, telling her that he was going to get rid of the baby. ${ }^{28}$

Despite her promise to Beverly, Dixie left Scott on a number of occasions, beginning in $1997 .{ }^{29}$ She always remembered her promise,

17. Id. at 444 .

18. Id. at 447. Batterers seek to isolate their victims from sources of support, like family members, in order to increase their control. PATRicia GagnÉ, BATTERED WOMEN's Justice: THE MOVEMENT FOR ClEMENCY AND THE POLITICS OF SELF-DEFENSE 19 (1998).

19. Transcript of Trial, supra note 3 , at 451 .

20. Id. at 452 .

21. Id. at 453 .

22. Id. at 456

23. Id. at 457 .

24. Id. at 446 .

25. Id. at 448 .

26. Id. at 458 .

27. Id. at $448-49$.

28. Id. at 458-59. A coworker of Dixie's confirmed that when Dixie was eight months pregnant with Ashley, she saw bruises and red marks on Dixie's stomach that Dixie told her Scott had caused. $I d$. at $658-59$. Battering often begins or increases in intensity when the victim becomes pregnant, and the fetus is frequently a target of the beatings. See Donna St. George, Many New or Expectant Mothers Die Violent Deaths, WASH. Post, Dec. 19, 2004, at A1 (reporting that for twenty-seven percent of abused women, abuse began during pregnancy and that for two-thirds of homicides of pregnant women, there was a "strong relation to pregnancy or . . . a domestic violenceclash in which pregnancy may have been a factor").

29. Transcript of Trial, supra note 3, at 457-58. 
however, and felt badly for leaving. "I had promised I would take care of him and I felt I wasn't doing that for her." ${ }^{30}$ Dixie also worried about her children growing up without a father. ${ }^{31}$ Each time she left, Scott would call Dixie, her family, and her friends relentlessly, asking her to come back and her friends to urge her to do so. ${ }^{32}$ He promised to change, to get counseling, to "do whatever it took to keep our marriage together." 33 And each time, Scott would change for a few months, would go to counseling, and would take his medication. ${ }^{34}$ But the beatings always resumed, becoming more severe, causing more serious injury. ${ }^{35}$

Although the beatings were a regular feature of Dixie's life with Scott, a number of particularly horrible incidents stood out in her testimony. The time that Scott threw her down the basement steps, chipping her front teeth (which remained chipped at the time of her trial, a number of years later). ${ }^{36}$ The time that Scott stuck her head in a toilet and told her that he would flush her head down the toilet, while her children watched. ${ }^{37}$ The time that Scott beat her on the top of the head with a cowboy boot. ${ }^{38}$ The time that Scott, angry about a red T-shirt that Dixie was wearing, poked her in the eye, causing the eye to bleed. ${ }^{39}$ The three times that Scott tied Dixie up, leaving her in their basement for up to two days, not allowing her to go to the bathroom, telling her, "You know, I could let you just sit here and die . . . and nobody would know the difference." 40

30. Id.

31. Id. at 457. Many victims cite concern for their children as a reason for remaining in an abusive relationship. ANGELA Browne, WhEn BAtTERED WOMEN KILL 110 (1987).

32. Transcript of Trial, supra note 3, at 675-76, 683. Coworkers and friends testified that Scott called repeatedly, asking and then demanding information about Dixie's whereabouts. Id.

33. Id. at 449-50, 459-60, 473-74.

34. Id. at $459,461-62,474$.

35. Id. at 450, 462. In the classic cycle of violence described by Dr. Lenore Walker in her 1984 book THE BATTERED WOMAN SYNDROME, the acute battering phase is followed by a honeymoon phase, during which the batterer vows to change and shows remorse for his behavior. WALKER, supra note 12, at 95-104. While the batterer may exhibit a short-term change, most frequently the violence begins again - and increases in intensity. Id.

36. Transcript of Trial, supra note 3 , at 460.

37. Id. at 461 .

38. Id. A coworker, Kristy Wessel, testified that Dixie told her she had a terrible headache as a result of being beaten with a cowboy boot. Wessel touched the top of Dixie's head and felt a number of lumps there that were painful to the touch. Id. at 673-74.

39. Id. at 469 .

40. Id. at 466-68. Two of these incidents followed Dixie's statements that she was going to leave Scott. Id. at 467-68. Violence often increases when the victim attempts to separate from her batterer; the batterer perceives he is losing control and uses physical violence to reinforce his control over his victim. See Martha R. Mahoney, Legal Images of Battered Women: Redefining the Issue of Separation, 90 MICH. L. REV. 1, 53-60 (1991) (describing how the batterer's loss of control over the victim at the time of separation can create grave danger for the victim). 
Two doors in the Shanahan home were damaged when Scott smashed Dixie's head into them-damage that still existed at the time of her trial. ${ }^{41}$ Scott smashed a plate of mashed potatoes over Dixie's head, complaining that they were runny. ${ }^{42} \mathrm{He}$ ran over her legs with a lawn tractor. ${ }^{43}$ He bit her, leaving a huge bruise on her leg. ${ }^{44}$ He threw tools at her face, causing a black eye. ${ }^{45}$ All of these incidents were in addition to the regular beatings. Scott also verbally abused Dixie, both privately and publicly, telling her friends they should teach her to be better in bed because she was terrible, no good, and worthless. ${ }^{46}$

Although Dixie recalled being beaten regularly over the course of their relationship, she reported the abuse to the police on only three occasions, the first in May of $1997 .^{47}$ After punching her in the face and slamming her head into the window of their car, he threatened to take their son, Zachary, and leave so that Dixie would never see the boy again. $^{48}$ On that occasion, Scott pled guilty to domestic abuse assault and was sentenced to thirty days in jail "with all but two days suspended and ... given credit for time served." "49 On September 8, 1997, Dixie again asked the police for help after Scott struck her head and legs with a metal object, causing her to bleed from the ear. ${ }^{50}$ Dixie told police at that

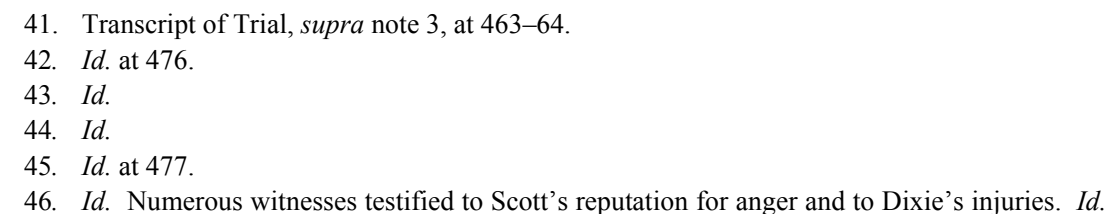
at $615-19,623-24,628-29,636,641-42,648-49,652-55$. Coworkers testified that she always wore long sleeves to work in the summer to cover the bruises on her arms. Id. at 632, 677. The Shanahans' neighbor testified that on more than one occasion she heard Scott yelling obscenities and threats at another person and a female voice screaming in pain. Id. at 687-88.

47. Id. at 178-80, 445. Aaron Anderson, a former Shelby County deputy sheriff, confirmed that Dixie Shanahan called for assistance in May of 1997 after Scott Shanahan back-handed Dixie across the face with a closed fist, bruising her eye and bloodying her lip. Id. at 178-80. He also recalled Dixie telling him that the abuse "had been going on for some time." Id. at 178-80. Scott Shanahan was arrested the following day. Id. at 180,710-11. Police had also received an earlier report, on November 19, 1996, from an attorney in Harlan telling them to take any report of domestic abuse from the Shanahan home seriously. Id. at 209, 709. That report came from Susan Christensen. Id. at 709; see also infra Part III.B (discussing the testimony of Susan Christensen).

48. Transcript of Trial, supra note 3, at 446.

49. Id. at 216-17. A no contact order was entered in the case; Dixie requested that that order be lifted in July 1997, saying,

I am no longer afraid that I will - that he will hurt me and I would like to keep my marriage together and with the restraining order this is not possible to try. $\mathrm{He}$ is in counciling (sic) now and I feel this is helping him. We have a [nine] month old son so if at all possible I would like this lifted so we can work this out.

Id. at 217. The court lifted the order the next day. See id. at 217 (stating that the application was filed on July 1 and the order lifted on July 2).

50. Id. at $186-87$. 
time that she was pregnant and afraid that Scott would cause her to lose the baby. ${ }^{51}$ Scott pled guilty to domestic abuse assault (an aggravated misdemeanor) and "was sentenced to serve two years in the state penitentiary with all but four days suspended." 52

The final police interaction with the Shanahans prior to August 2002 occurred on October 9, 2000. ${ }^{53}$ Dixie's friends tried to enter the home; Scott would not let them in and they called the police. ${ }^{54}$ When the deputies arrived, Scott refused to open the door and put Dixie and the children in a closet, holding the door closed with his foot. ${ }^{55}$ A friend remembered, however, that Dixie kept a key hidden in back of the house and the deputies used the key to enter and arrest Scott. ${ }^{56}$ Deputy Sheriff Mark Hervey observed that Dixie had two black eyes. ${ }^{57}$ Dixie told Hervey that one had been caused when Scott threw a VCR tape at her; the other resulted from being poked in the eye. ${ }^{58}$ Dixie also showed Deputy Hervey the hole in the door that Scott made with her head. ${ }^{59}$ Deputies arrested Scott and charged him with false imprisonment and felony domestic abuse assault with injury. ${ }^{60}$ Dixie fled to Texas, where she stayed until April 2001. ${ }^{61}$ In the interim, Scott repeatedly contacted her in violation of the no contact order entered in the criminal case, ${ }^{62}$

51. Id. at 205 .

52. Id. at 222. Dixie had asked for the charges against Scott to be dropped, stating,

I know he has been attending his BEP classes as required and also on his own has been seeing a councler (sic) and a psychiatrist so he has been - so he is making every effort to get help. I cannot see where jail time would be beneficial to him at all.

In all fairness some of the things I said were exaggerated and this whole thing has been blown out of proportion.

$I d$. at 221. On cross-examination, Vicky Krohn, the clerk of court for Shelby County, acknowledged that many victims of violence ask that domestic violence complaints be dismissed, a point Susan Christensen also grudgingly conceded. $I d$. at $226,730-31$. In fact, victim reluctance to assist with prosecution is so common that prosecutors developed "victimless" prosecution techniques in order to proceed with domestic violence cases even when the victim declines to cooperate. See, e.g., Cheryl Hanna, No Right to Choose: Mandated Victim Participation in Domestic Violence Prosecutions, 109 HARV. L. REV. 1849, 1860-65 (1996) (discussing aggressive prosecution policies and their impact on domestic abuse)

53. See Transcript of Trial, supra note 3, at 189-92 (describing police arrival and entry into the house).

54. Id. at $470-72$.

55. Id.

56. Id.

57. Id. at 191

58. Id.

59. Id. at 193

60. Id. at 196 .

61. Id. at 472 .

62. Id. at 209. Deputy Hervey testified that he knew Scott had been contacting Dixie in Texas, in violation of the no contact order. Id. Teresa Merritt, a friend of Dixie's, testified that while Dixie 
begged her to come back, and threatened to kill himself. ${ }^{63}$ Scott finally went to Texas to convince Dixie that he could be a good husband and to tell her that he had hepatitis A and was going to die. ${ }^{64}$ Dixie refused to return to Defiance to testify against Scott, and the charges against him were dismissed. $^{65}$ But after Scott's repeated entreaties, Dixie later returned to Defiance. ${ }^{66}$

By August 2002, Dixie was being physically abused three to four times weekly, leaving her badly bruised. ${ }^{67}$ She also learned that once again, she was pregnant. Scott, enraged, demanded that she have an abortion. Dixie refused. ${ }^{68}$ Scott repeatedly beat Dixie and told her that she was not going to have the baby, that he would make sure that she would not have the baby, and that there was nothing she could do about it. ${ }^{69}$ On August 30, angry because Dixie failed to wake him before their son, Zachary, left for the school bus, Scott began beating Dixie's stomach, screaming, "I'm gonna' kill this baby one way or another""70 while their daughter, Ashley, watched. ${ }^{71}$ Dixie sent Ashley to a friend's house and tried to leave the house herself. ${ }^{72}$ Scott took her car keys, knocked her to the ground, and dragged her into the house by her hair, pulling chunks of hair out of her head. ${ }^{73}$ He then punched her stomach again, screaming that she would not have the baby. ${ }^{74}$

Scott left the room as Dixie lay on the floor crying. ${ }^{75}$ He returned with a shotgun, enraged, visibly shaking, and calling Dixie obscene names. $^{76}$ He jammed two different shells into the gun, then pointed the gun at Dixie, and said, "This day is not over yet. I will kill you.,"77 Dixie

was in Texas, Scott admitted to beating Dixie and the children and tying Dixie up in the basement. He said he did not blame her for leaving. Id. at 642 .

63. Id.

64. Id. at 472-74. Deputy Sheriff John Kelly testified that on Christmas Eve, 2000, he responded to a call about a suicide threat at the Shanahan residence. Kelly found Scott Shanahan there, alone, visibly upset and shaking, saying that he had nothing to live for if he did not get Dixie back and because she was not there. Id. at 277-79.

65. Id. at 199 .

66. Id. at 474 .

67. Id. at $479-80$.

68. Id. at 480

69. Id. at 481 .

70. Id. at $482-83$.

71. See id. at 483 (containing Dixie's statement that she "sent Ashley out of the house 'cuz [she] didn't want her to see" the beating).

72. Id. at $483-84$.

73. Id. at 484 .

74. Id. at $484-85$.

75. Id. at 485 .

76. Id.

77. Id. at 485-87. The prosecution suggested that Dixie, who had no experience with shotguns, 
was sure that he would shoot her, but he did not; instead, Scott began beating her again, threatening to kill her and the baby. ${ }^{78}$ At some point, Scott also removed the phones from their jacks. When he stopped beating Dixie, he went into the bedroom, taking the phones with him. The only working phone was in the bedroom with him. ${ }^{79}$

Dixie decided she needed to call the police and went into the bedroom to attempt to use the phone. ${ }^{80}$ As she tried to grab the phone, Scott moved towards her. ${ }^{81}$ Seeing the shotgun near the phone, Dixie grabbed it, closed her eyes, and shot Scott. ${ }^{82}$ Dixie testified that she believed that Scott was coming for her again and that she had no other choice, that the only way to protect herself and her unborn child was to shoot Scott Shanahan. ${ }^{83}$ She then sat in a chair outside the bedroom for a few hours, wondering what she was going to do. ${ }^{84}$ Ultimately, she put the gun in the closet of the children's bedroom, shut the door to the bedroom where Scott lay dead on the bed, put a towel underneath the door, and went back to the chair, where she sat until her daughter came home that afternoon. ${ }^{85}$ She never told anyone that Scott was in the bedroom, ${ }^{86}$ where he remained until the police searched her home on October $20,2003 .^{87}$

\section{DiXIE SHANAHAN IN THE CONTEXT OF BATTERED WOMEN WHO KILL}

Dixie Shanahan's case became notorious because Scott lay dead in the back bedroom of her home for eighteen months while she and her children continued to live in the house. Without that sensational detail, her story would not have been significantly different from those of the thousands of other women currently serving sentences for killing their abusive partners. What transforms these women from victims of severe abuse to killers?

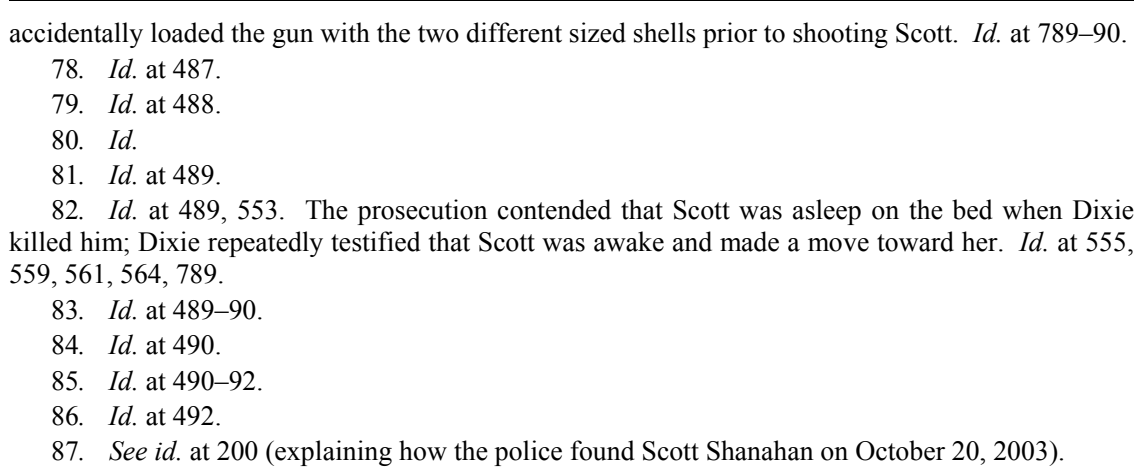




\section{A. Understanding Battered Women Who Kill}

Studies consistently find that large percentages of the women incarcerated for murder or manslaughter are in prison because they killed intimate partners who had abused them. ${ }^{88}$ Many of these women-like Dixie Shanahan - are first-time offenders who have no prior history of violence. $^{89}$

Battered women who kill share a number of characteristics. Few have resorted to violence against their abusers in the past. As Angela Browne notes, "Women charged in the death of a mate have the least extensive criminal records of any female offenders." endured repeated, severe abuse over a period of years. ${ }^{91}$ At some point, the violence against them escalated to a level where the battered woman believed that if she did not kill her abuser, she would be killed. ${ }^{92}$ Lenore Walker explains, "Battered women who kill their abusers do so as a last resort." 93 Sue Ostoff, who has represented more than 350 women who have killed their abusers, agrees: "I've met only one woman who wanted to kill her husband. Battered women don't want to do it. And

88. See, e.g., CORR. ASS'N OF N.Y., BREAKING THE SILENCE: WOMEN IN PRISON = UNEQUAL JUSTICE 3 (1991), available at http://www.barnard.columbia.edu/bcrw/archive/prison/ BreakTheSilence.pdf [hereinafter BREAKING THE SILENCE] (reporting a New York State Survey's finding that $49 \%$ of women committed to New York prisons for homicide in 1986 were victims of abuse and that the abuser was living with or married to the woman in $89 \%$ of those cases); Christopher A. InNes \& Lawrence A. Greenfeld, U.S. Dep'T of Justice, Violent State PRISONERS AND THEIR VICTIMS 6 tbl.12 (1990) (reporting that 37.7\% of the homicide victims of first-time female offenders in state prisons were spouses, ex-spouses, or other intimates of the offender); NAT'L Clearinghouse FOR THE DeF. OF BATTEREd WOMEN, Statistics PACKet 53 (3d ed. 1994) (reporting that $40 \%$ of the women incarcerated in Chicago "for murder had killed partners who had repeatedly abused them"); Kathleen A. O'Shea, Women on Death Row, in WOMEN PRISONERS: A FORGOTTEN POPULATION 75, 85 (Beverly R. Fletcher et al. eds., 1993) (reporting 1992 data showing that, of the 235 women incarcerated for homicide in Georgia, 44\% killed a husband or lover, and that 46 of these women were abused by their partners). Of the 70,300 women incarcerated in state prisons in 1998, just over 11\% were in prison for homicide. ALLEN J. BECK, U.S. DeP'T OF JustiCE, PRisONERS IN 1999, at 10 tbl.15 (2000).

89. See Press Release, Corr. Ass'n of N.Y., New York Group Calls on State Lawmakers to Release Women in Prison (Mar. 4, 1991), reprinted in BREAKING THE SILENCE, supra note 88, at 6 (noting that for over half the women convicted of homicide in 1986 in New York state prisons, this was their first and only offense).

90. BROWNE, supra note 31, at 11.

91. See GAGNÉ, supra note 18, at 24 ("Many battered women live with violence and abuse for years.").

92. Id. at 28; Linda L. Ammons, Dealing with the Nastiness: Mixing Feminism and Criminal Law in the Review of Cases of Battered Incarcerated Women -A Tenth-Year Reflection, 4 BufF. CRIM. L. REV. 891, 913 (2001).

93. Lenore E. Walker, Terrifying Love: Why Battered WOMEN Kill and How SOCIETY RESPONDS 5 (1989). 
they won't do it if they don't absolutely have to.",94 One battered woman who killed her partner described her experience: "II would have been dead, in a short time, Tommy would have killed me. I know he would have. I know he would have." "95

Battered women who kill have frequently tried to leave their abusers but have found that police, clergy, courts, shelters, or other resources were either not available or not helpful in stopping the violence. ${ }^{96}$ In addition, battered women are aware of the tenuous nature of the protection available through the legal system. They read newspaper stories and watch television accounts about women who have called the police and obtained orders of protection, only to be killed by their abusers. " "When 'media tragedies' like these hit the news, battered women get the message: the system that fails to protect them from assault at home will not protect them when they leave."

\footnotetext{
94. ANN JoNES, WoMEN WHo KILL 346-47 (1996).

95. Amy Lou Busch, Finding Their Voices: Listening to BATTEREd Women Who’ve KILLED 53 (1999).
}

96. See BrownE, supra note 31, at 159, 170 (“A lack of effective legal protection from assaults and threats by marital partners sets up the conditions whereby victims may finally believe it necessary to protect themselves."); GAGNÉ, supra note 18, at 27 ("Although the wife may have called the police on many occasions, sought help from clergy, and left home, over time she may have learned that help was not available and that permanently escaping from the relationship with several children was impossible for her."). One study suggests that battered women leave but return to their relationships unwillingly - because of threats or further violence, for their children, or because they have no other place to go. JONES, supra note 94, at 297. For a discussion of barriers to leaving abusive relationships, see BROWNE, supra note 31, at 109-28; GAGNÉ, supra note 18, at 81-82.

97. Legislators in North Carolina have crafted an ironic solution to this problem. Recognizing that a protective order "[t]oo often . . . amounts to a useless piece of paper," North Carolina recently passed a law making it easier for victims of domestic violence to obtain emergency concealed handgun permits so long as the sheriff agrees. Editorial, Gun May Raise Risks, GREENSBORO NEWS \& REC. (N.C.), Aug. 20, 2005, at A8. Governor Mike Easley signed the bill, but asked the legislature to remove language that required court clerks to inform women getting protective orders about the provision. Amy Gardner, Domestic Violence Bill Signed, News \& OBSERVER (Raleigh, N.C.), Aug. 30, 2005, at 1B. Of course, if these women choose to use their weapons to protect themselves, they may find themselves in the same situation as Dixie Shanahan and other battered women who have killed, trying to persuade juries that their lives were in imminent danger. See Joan Ryan, A Woman, a Batterer and a Gun, S.F. CHRON., Jan. 8, 2006, at B1 (describing how a battered woman who carried a concealed weapon was convicted of carrying a loaded gun when her protective order expired).

98. JONES, supra note 94, at 345 . Yvette Cade's case provides a graphic, horrifying example of the system's failure to protect a battered woman. On September 19, 2005, Judge Richard A. Palumbo vacated Yvette Cade's protective order against her husband, Roger Hargrave. Allison Klein \& Ruben Castaneda, Md. Victim of Burning Told Judge of Fears, WASH. Post, Oct. 13, 2005, at B1. Ms. Cade pleaded with the judge not to lift the order, telling the judge that her husband continued to terrorize her and her daughter. Id. When Ms. Cade told the judge that she wanted to divorce her husband (instead of entering counseling with him, as Mr. Hargrave had suggested in his motion to vacate the order), Judge Palumbo responded that he wanted " "to be six-foot-five, ... [b]ut that's not what we do here." Id. Judge Palumbo told Ms. Cade that she needed to hire an attorney and go to divorce court-ignoring that her pleas for continued protection related not to her desire for 
Angela Browne identifies a number of variables that make battered women more likely to kill their partners. These include the increased frequency of abusive incidents, the severity of the woman's injuries, the frequency of forced or threatened sexual acts, the man's drug use or frequent intoxication, an increase in the man's threats to kill, and the woman's threats of suicide. ${ }^{99}$ Battered women who kill frequently report the destruction of their pets; these women believe that the murder of a pet represents their own imminent deaths. ${ }^{100}$ All of these variables point to the escalating danger these women perceived and their increasing beliefs that they would be unable to escape. Browne explains,

[T] he women's behavior seemed to be primarily in reaction to the level of threat and violence coming in. Women in the homicide group reported that they had felt hopelessly trapped in a desperate situation, in which staying meant the possibility of being killed, but attempting to leave also carried with it the threat of reprisal or death. Their sense of helplessness and desperation escalated along with the assaultive behavior of their partners. ${ }^{10}$

Browne uses social judgment theory to explain the thought processes of battered women before they kill. ${ }^{102}$ Browne argues that a "latitude of acceptance" defines what battered women believe they can live through. ${ }^{103}$ The parameters of that latitude constantly shift to assimilate attacks that previously they would not have believed they could survive. ${ }^{104}$ When acts occur that the women perceive as significantly outside of the "normal" range of violence (a change in the pattern of violence, or more brutal behavior) or that is beyond the range of what they can assimilate (like child abuse), that "contrast phenomena" indicates to the women that their deaths are imminent. ${ }^{105}$ At that moment, "[t]heir final hope had been removed. They did not believe

\footnotetext{
a divorce, but to the violence against her-and dismissed the order that Ms. Cade obtained in July Id. Three weeks later, Mr. Hargrave entered the T-Mobile store where Ms. Cade worked, poured gasoline on her, and set her on fire. Id. Ms. Cade remained hospitalized with third degree burns to her face and more than half of her upper body for months. Id.; see also Betty Cuniberti, Kelli Alexander Did Everything Right. Did It Have to Cost Her Life?, ST. LouIs Post-DisPatch, Mar. 2, 2005 , at E1 (describing how the system also failed to protect Kelli Alexander).

99. BROWNE, supra note 31, at 127.

100. Id. at 157 .

101. Id. at 127 .

102. Id. at 128 .

103. Id. at $128-30$.

104. Id. at 128-29.

105. Id.
} 
they could escape the abusive situation and survive, and now they could no longer survive within it either."106

Battered women are particularly likely to kill when they perceive that their own lives or the lives of their children are immediately imperiled. ${ }^{107}$ This fight or flight response should be seen as psychologically normal, Lenore Walker argues: "Defending oneself from reasonably perceived imminent danger of bodily harm or death ought to be considered a psychologically healthy response." 108 But the women do not necessarily make a conscious decision to save themselves at the expense of their partners; while they may have had "an absolute conviction that death was inevitable within a certain timeframe," the women usually believed that they or their children, and not the abuser, would be the victims if someone died. ${ }^{109}$ As Browne explains, "Typically the killing of the abuser was unplanned and occurred in the midst of an attack against the woman, during the warning phase when it became apparent that an attack was about to begin, or during an escape attempt by the woman."110 And what of battered women who kill their partners after an attack or while they sleep? Browne explains that "[t]hese delayed homicides were often related to an explicit threat by the abuser to 'get' the woman or a child within a specific time; women killed the abuser to avert the threatened outcome."

The abuser's power over a battered woman who kills may be so great that the woman continues to believe the abuser is dangerous even after he is dead and takes measures to protect herself. As Browne notes, "One woman locked her husband's body in the closet after she shot him: As long as she could see him, she was afraid he was going to reach out and grab her." "112 Walker states, "Even after a homicide, denial and the battered woman's belief in the omniscience of her batterer serve to

106. Id. at 130 .

107. GAGNÉ, supra note 18 , at 24.

108. WALKER, supra note 93, at 169.

109. BROWNE, supra note 31 , at 135 .

110. Id. at 135-36. A review of the social science literature suggests that over seventy percent of battered women who kill do so either during an attack or when facing imminent death or serious bodily injury; the number may actually be closer to ninety percent. Holly Maguigan, Battered Women and Self-Defense: Myths and Misconceptions in Current Reform Proposals, 140 U. PA. L. REV. 379, 384 (1991).

111. BROWNE, supra note 31, at 136. One commentator suggests that battered women kill when their partners are sleeping or not expecting to be attacked to overcome differences in physical size and strength. Bobbi J. Vilachá, More Than Victims: Battered Women, the Syndrome Society, and the Law, 20 WOMEN's RTS. L. REP. 43, 44 (1998) (book review).

112. BROWNE, supra note 31 , at 141 . 
deaden death's effect." ${ }^{\text {"13 }}$ When they are able to come to grips with what they have done, however, battered women who kill most often report feeling sorrow and horror at the deaths of their partners. ${ }^{114}$

\section{B. Dixie Shanahan as a "Typical" Battered Woman Who Kills}

If such a thing as a "typical" battered woman who kills exists, Dixie Shanahan seems to be one. She was a first-time offender with no history of violence; she was a nurturing woman whose work involved caring for the elderly and frail in nursing homes. Scott Shanahan abused her for the entire nineteen years of their relationship, abuse that escalated in both frequency and severity over time. Dixie repeatedly tried to leave Scott, turning to family and friends for assistance, fleeing the state, but ultimately being begged and bullied back to him each time, with her promise to his mother Bev echoing in her head.

Particularly noteworthy, and consistent with the experiences of other battered women who have killed, was the response of the legal system to Scott's repeated abuse. At the murder trial, Susan Christensen, the assistant county attorney for Shelby County, testified to her interactions with Dixie Shanahan. In her role as assistant county attorney, Christensen was responsible for prosecuting misdemeanor domestic violence cases. ${ }^{115}$ Christensen also maintained a private practice, specializing in family law. ${ }^{116}$ Christensen told the jury that she met with Dixie Shanahan in November 1996, when Dixie came to her seeking advice about how to handle Scott's violence. Christensen advised Dixie to petition the court for a civil protective $\operatorname{order}^{117}$ and discussed instituting criminal proceedings with her. Christensen testified that while Dixie was not ready to lodge criminal charges against Scott, she did begin to fill out the papers for a protective order. ${ }^{118}$ After that conversation, Christensen was sufficiently concerned for Dixie's safety that she called the sheriff's office and told them that if they got a call from the Shanahan home, "they should take it very seriously." 119

113. WALKER, supra note 93 , at 73.

114. BROWNE, supra note 31, at 141 .

115. Transcript of Trial, supra note 3 , at 698 .

116. Id. at 700. Christensen estimated that about a quarter of her family law cases involved domestic violence. $I d$.

117. See Catherine F. Klein \& Leslye E. Orloff, Providing Legal Protection for Battered Women: An Analysis of State Statutes and Case Law, 21 HofSTRA L. ReV. 801, 811-14 (1993) (discussing uses of civil protection orders).

118. Transcript of Trial, supra note 3, at 707. In Iowa, such orders are known as 236 orders. Id.

119. Id. at 709 . 
Christensen later learned that Dixie never returned to the clerks' office to complete the paperwork. ${ }^{120}$ Three months later, however, Dixie went to court and was granted a protective order, which was in place at the time of Scott's first criminal trial on June 23, $1997 .^{121}$

Christensen described Dixie as initially cooperative during the first criminal trial, which Christensen prosecuted. $^{122}$ On July 2, 1997, however, after Scott pled guilty and served two days in jail for punching Dixie, Dixie asked that the protective order be lifted. ${ }^{123}$ While Christensen testified that to her knowledge, no violation of the protective order was ever reported, ${ }^{124}$ a cursory glance at the timeline Christensen provided makes it clear that if Dixie Shanahan obtained a protective order three months after she first visited Christensen in November 1996 which was still in effect at the time of the trial, the events that caused Scott Shanahan to plead guilty in June 1997 were a violation of that first protective order.

Christensen again prosecuted Scott Shanahan when he was charged with domestic abuse assault in September 1997, just three months after his first conviction. ${ }^{125}$ Dixie did not assist the prosecution on that occasion; instead, she sent the court a letter stating that she had exaggerated the violence and asking that the charges be dismissed. ${ }^{126}$ But police reports reflect the seriousness of the injuries Dixie Shanahan sustained and a sheriff's deputy photographed those injuries. ${ }^{127}$ On that occasion, Scott Shanahan served four days in jail. ${ }^{128}$

Christensen was also involved with the third case against Scott Shanahan, the felony prosecution in October 2000. After the incident leading to that prosecution, Dixie fled to Texas, giving prosecutors

\footnotetext{
120. Id. at 710 .

121. Id. at 711 .

122. Id. at 712 .

123. Id. at 712-13. Dixie provided supporting documentation for the request from a clinical psychologist at Prairie Rose Mental Health, which suggests that Scott had, as promised, sought counseling. $I d$. at 713 .

124. Id. at 714 .

125. Id.

126. Id. at 715-16. Recantation is a recurrent theme in criminal prosecutions involving battered women. Police and prosecutors have experimented with a number of policy solutions to that problem, including victimless prosecution, no-drop prosecution policies, and compelling the victim's attendance. See, e.g., Deborah Epstein et al., Transforming Aggressive Prosecution Policies: Prioritizing Victims' Long-Term Safety in the Prosecution of Domestic Violence Cases, 11 AM. U. J. GENDER SOC. POL'Y \& L. 465, 486-98 (2003) (discussing various prosecution policies).

127. Transcript of Trial, supra note 3 , at 187 . Unfortunately, the testimony of the deputy who responded, Brad McQueen, was not available, as he had sustained a head injury that impaired his memory. Id. at 185.

128. Id. at 716
} 
"some comfort knowing that there was some distance between the two." 129 But that comfort turned to distress when Dixie refused to return from Texas to testify and prosecutors were forced to drop the charges against Scott Shanahan. ${ }^{130}$

Susan Christensen testified that she believed that if Dixie Shanahan had cooperated with the third prosecution, the legal system would have protected her, would have stopped the violence. Christensen stated, "[T]here were choices that we gave Dixie, in particular, that she chose not to take and those choices have been proven over and over to be effective if allowed to take their course."131 But Christensen's own testimony shows that Scott Shanahan was not the type of batterer who was deterred by the legal system. ${ }^{132}$ Dixie got a restraining order. Scott violated it. ${ }^{133}$ She pursued criminal charges. Scott served two days in jail, was ordered to participate in batterer's intervention counseling, ${ }^{134}$ and nonetheless was arrested and convicted again for assaulting Dixie just three months later. On that occasion, he served four days in jail. When he was released, he began abusing Dixie anew. ${ }^{135}$ What was the sum total of Dixie Shanahan's experiences with the legal system? Three cases, six days in jail, and one order that Scott attend counseling. The violence continued unabated, increasing in frequency and severity, in

129. Id. at $717-18$.

130. Id. at $718-19$.

131. Id. at 728. Not everyone shares Christensen's belief in the effectiveness of these strategies. For a discussion of the many ways that the legal system can fail battered women, see generally Leigh Goodmark, Law Is the Answer? Do We Know That for Sure? Questioning the Efficacy of Legal Interventions for Battered Women, 23 ST. LOUIS U. PUB. L. REV. 7 (2004).

132. Abusive men with violent criminal histories - like Scott Shanahan - are more likely to violate protective orders than other men. Joan Zorza \& Nancy K.D. Lemon, Two-Thirds of Civil Protection Orders Are Never Violated; Better Court and Community Services Increase Success Rates, in Violence Against Women: Law, PreVention, Protection, Enforcement, Treatment, Health 28-1, 28-1 to -2 (Joan Zorza ed., 2002). As Judge Albert Kramer, of the Quincy, Massachusetts District Court notes, “"There is no other group of perpetrators of violence that is more tenaciously resistant to court orders and court efforts to curb their violence and prevent their almost relentless pursuit of their victims." JAMES PTACEK, BATTERED WOMEN IN THE COURTROOM: THE POWER OF JUdicial RESPONSE 85 (1999).

133. Scott Shanahan not only violated the first protective order, as Susan Christensen's testimony shows, but also the no contact order that had been filed at the time of the third prosecution. Deputy Mark Hervey testified that he had heard that Scott had been contacting Dixie in Texas in violation of the no contact order, but apparently Hervey took no action. Transcript of Trial, supra note 3 , at 209 .

134. Id. at 712-13.

135. Christensen admitted on cross-examination that in her experience, about half of the women who got restraining orders reported further problems. The other half either experienced no difficulties or simply did not report them. Id. at 733. These numbers refute Christensen's assertion that legal action can be counted on to prevent further abuse. Christensen also acknowledged that many victims of violence have little faith in the ability of protective orders to keep them safe. $I d$. at 736. 
spite of those interventions. By the time of the third criminal case, Dixie Shanahan knew the legal system could not or would not keep Scott Shanahan from abusing her. It is hardly surprising she chose to remain in Texas rather than returning to Iowa to cooperate with the third prosecution. Like many battered women who kill, it must have been clear to Dixie Shanahan that the police and courts had little to offer her by way of protection. ${ }^{136}$

By August of 2002, the abuse against Dixie Shanahan reached new levels of frequency and severity. Scott's threats to kill her became more frequent. And on August 30, 2002, Dixie was finally confronted by abuse that she could not assimilate - the credible threat to kill her unborn child. Scott repeatedly threatened to kill both Dixie and the baby, telling her they would be dead before the day was over. It was the certainty that Scott would kill her unborn child that day that finally led Dixie to strike back. ${ }^{137}$ Dixie's actions were consistent with those of other battered women who kill not in the midst of a battering incident, but during a lull, having been told that the batterer will begin the violence again, and knowing that this time he will not stop until she and her unborn child are dead.

So Dixie Shanahan shot and killed Scott Shanahan, and the criminal justice system, which never adequately protected her, found her guilty of second-degree murder and sentenced her to fifty years of imprisonment. The conviction was certainly a legally permissible outcome. The evidence was sufficient for a jury to find, beyond a shadow of a doubt, that Dixie Shanahan committed second-degree murder. But the conclusion that the verdict was legally sound should not be the end of the analysis, as the residents of Defiance, Iowa, stunned by the sentence, recognized. The next Part asks: Even if she was legally culpable for his death, was punishing Dixie Shanahan for shooting Scott Shanahan just?

136. Dixie lacked access to other resources to escape the violence. Because of the lack of services for battered women in rural Iowa, Dixie would have needed to travel at least forty miles to access services. Jeff Eckhoff, Most Iowa Counties Lack Havens for Women, DES MoINES REG., May 1, 2004, at 1A.

137. Before Dixie disclosed to anyone that she killed Scott, she told friends and acquaintances he had left the home on her demand. Kathryn Myers testified that Dixie told her she wanted Scott out of her life because she was afraid for her unborn child's life. Transcript of Trial, supra note 3, at 314. When Dixie finally confessed to Kathryn Myers that she shot Scott, shortly before the police apprehended her, she clutched her stomach, as if to protect that child, named Brittany. Id. at 326. 


\section{JUSTICE AND THE PUNISHMENT OF DiXIE SHANAHAN}

Criminal punishment is "the infliction by state authority of a consequence normally regarded as an evil (e.g., death or imprisonment) on an individual found to be legally guilty of a crime." 138 Punishments are generally unwelcome to the recipient; intentional and imposed for a reason; ordered by those regarded as having a right to do so; inflicted as a result of an infringement of law, rule, or custom; imposed upon someone who played a voluntary part (or is viewed as having played a voluntary part) in the infringement; justified by the punisher; and intended to be perceived as punishment by the punisher. ${ }^{139}$ Punishment in the criminal system can be justified under a number of theories. If, however, a punishment satisfies none of those theories, that punishment cannot be considered just. This Part reviews the four major theories underpinning criminal punishment in the United States, then asks whether punishing Dixie Shanahan was justified under any of those theories.

\section{A. Theories of Criminal Punishment}

Criminal punishment is generally justified by one of four theories: retribution, deterrence, incapacitation, and rehabilitation. ${ }^{140}$ Each of these theories will be considered in turn, then applied to the case of Dixie Shanahan.

138. JefFrie G. Murphy \& Jules L. Coleman, The Philosophy of LaW: An Introduction TO JURISPRUDENCE 123 (1984).

139. Nigel Walker, Why Punish? 1-3 (1991). H.L.A. Hart defines punishment as involving pain or other unpleasant consequences, for an offense against legal rules, of an actual or supposed offender for that offense, intentionally administered by someone other than the offender, and imposed by the legal system. H.L.A. HART, PUNISHMENT AND RESPONSIBILITY: ESSAYS IN THE PHILOSOPHY OF LAW 4-5 (1968). Herbert Packer adds that punishment is "imposed for the dominant purpose of preventing offenses against legal rules or of exacting retribution.” HERBERT L. PACKer, THE Limits of the CRIMINAl SANCTION 31 (1968). Critics of criminal punishment counter that there is no consensus about the nature or functions of punishment, that punishment can just as easily be seen as a means of perpetuating an unjust status quo or oppressing citizens as it can "a reaffirmation of the community's ethical values" or a defense against anarchy. AM. FRIENDS SERV. COMM., StRUGGLE FOR JUSTICE 10 (1971).

140. Leon Radzinowicz argues that looking for a single justification for punishment is as useless as looking for a single cause of crime. LEON RADZINOWICZ, IDEOLOGY AND CRIME 115 (1966). 


\section{Retribution}

Retribution is the oldest moral underpinning for criminal punishment, dating back to the Code of Hammurabi, developed by the Babylonians around the eighteenth century B.C. ${ }^{141}$ The lex talionis, or law of retaliation, limited all sentences to punishment proportionate to the crime - an eye for an eye, a life for a life. ${ }^{142}$ Retributive theory has since evolved to include a number of different moral justifications for criminal punishment, all resting on the notion that punishment is necessary to give the criminal what she deserves as a result of her wrongdoing. The notions of criminals paying for their crimes, paying their debts to society, or getting what is coming to them all grow out of retributive theory. ${ }^{143}$ While modern retributive theory no longer requires "eye for an eye" punishment, it continues to maintain that punishment should be proportionate to the crime committed. ${ }^{144}$

"Retributive conceptions of criminal punishment rest essentially on the inherent propriety of punishment as a consequence of wrongdoing, that is, it amounts to an obligation to be settled in an accounting among the offender, the victim, and society." 145 While that obligation is at the core of retributivist theory, theorists have posited a number of different explanations for why that obligation exists. ${ }^{146}$ According to Emmanuel Kant, for example, punishment was a categorical imperative; the imposition of punishment was not just permissible, but morally required simply because wrongdoing had occurred. ${ }^{147}$ Punishment restores the

141. Kathleen Dean Moore, Pardons: Justice, Mercy, and the Public Interest 15 (1989).

142. Id. at 16.

143. PACKER, supra note 139, at 10.

144. HART, supra note 139, at 234. Retributive theorists argue that retribution should not be confused with revenge. Some key differences: retribution rights a wrong, while revenge can be for something other than a moral wrong; retribution sets limits to the appropriate punishment, while revenge can be (and frequently intentionally is) disproportionate; revenge is personal, while retribution does not rely on personal ties; revenge involves pleasure in the suffering of another, while retribution lacks this emotionalism; revenge is not general - the avenger is not committed to seeking it again in similar circumstances; retribution is visited only upon the wrongdoer, while revenge can involve innocent persons close to the person revenge is being sought against. C.L. TEN, CRIME, Guilt, AND Punishment: A Philosophical InTROduction 42-43 (1987). One prominent retributive theorist now believes that the two may not be as separable as he previously believed, however. JEFFRIE G. MURPHY, RETRIBUTION RECONSIDERED 85 (1992).

145. AM. FRIENDS SERV. COMM., supra note 139, at 48.

146. For an overview of these theories, see WALKER, supra note 139, at 73-82.

147. HART, supra note 139 , at 232. 
moral balance that is upset when a crime occurs. ${ }^{148}$ John Rawls states, "[P]unishment is justified on the grounds that wrongdoing merits punishment."149 Others have similarly argued that the punishment negates the wrongdoing, creating the sense that the wrongful act never happened. ${ }^{150}$ Building on this theory, "[p]unishment annuls crime in the sense that it establishes that the victim has ... rights, and hence the criminal's denial of them is a mistake." ${ }^{\prime 51}$ Punishment, then, restores the rights intruded upon by the criminal to the extent that the punishment is commensurate to the amount of intrusion created by the crime. ${ }^{152}$

Another strain of retributive theory argues that "fairness dictates that a system in which benefits and burdens are equally distributed have a mechanism designed to prevent a maldistribution in the benefits and burdens. ... . [I]t is just to punish those who have violated the rules and caused the unfair distribution of benefits and burdens." need not be material, but rather can be the voluntary renunciation of restraining oneself from violating the law. Punishment deprives the offender of the ability to indulge his will by enjoying benefits made possible because others have assumed the burden of following the law, a burden the wrongdoer has renounced. ${ }^{154}$ Allowing the criminal to profit from his own wrongdoing is unjust not only to the victim, but to everyone who abides by the law. ${ }^{155}$ Punishment can also serve as communication with the offender under retributive theory. Robert Nozick describes punishment as "a communicative act transmitting to the wrongdoer . . . how wrong his conduct was."156 "[R]etributive

148. Gertrude Ezorsky, Introduction to Philosophical PersPeCtives on PUNISHMENT, at xvii (Gertrude Ezorsky ed., 1972).

149. John Rawls, Rule Utilitarianism (II), in Philosophical Perspectives on Punishment, supra note 148 , at 82,84 .

150. A.M. Quinton, On Punishment, in Philosophical PersPeCtives on Punishment, supra note 148 , at 6,7 .

151. TEN, supra note 144, at 39.

152. See RADZINOWICZ, supra note 140 , at 10 (““'[E]veryone must suffer punishment so far to invade the province of his own rights as the crime he committed has penetrated into that of another."').

153. Herbert Morris, Persons and Punishment, in Philosophical Perspectives ON PUNISHMENT, supra note 148, at 116, 117.

154. TEN, supra note 144, at 55.

155. JefFrie G. Murphy, Retribution, Justice, And Therapy 78 (1979). Murphy describes the criminal as a free rider in the scheme of social cooperation, enjoying the benefits of the rule of law without making the sacrifice of self-restraint required to sustain it. MURPHY, supra note 144, at 23.

156. TEN, supra note 144 , at 42 . 
punishment reconnects the offender with the correct values from which his [act has alienated] him."157

The idea of desert is central to retributive theory. As C.S. Lewis explained, "[T]he concept of Desert is the only connecting link between punishment and justice. It is only as deserved or undeserved that a sentence can be just or unjust." ${ }^{, 158}$ Desert is a moral concept, not a legal one. "[A] legal code cannot suffice to determine what a criminal deserves to suffer as a penalty. The misery he deserves depends on the moral wrong he has committed." "59 John Rawls concurs: "That a criminal should be punished follows from his guilt, and the severity of the appropriate punishment depends on the depravity of the act." 160 Desert should also be individualized; as no two crimes are the same, no two punishments should be. ${ }^{161}$

Why is retribution preferable to other theories of punishment? Retributivists argue that retribution "promises the certainty which utilitarianism cannot. The punisher can be sure that whatever else he may or may not be achieving he is at least inflicting more or less what the offender deserves." 162 Punishment in and of itself is the end of retributivists; punishment need have no other benefit, either to the individual being punished or to society. As Herbert Packer explains, "[M]an is a responsible moral agent to whom rewards are due when he makes right moral choices and to whom punishment is due when he makes wrong ones. . . . These imperatives flow from the nature of man and do not require-indeed do not permit - any pragmatic justification." 163 Others argue, however, that retributive theory debases individuals to serve a theory.

The retributive view of punishment justifies the infliction of evil upon a living soul, even though it will do neither him nor any one else any good whatever. ... It is the retributive theory which shows a disrespect for human personality by proposing to sacrifice human life and human Well-being to a lifeless fetish styled the Moral Law, which apparently,

157. Id. at 45 .

158. C.S. Lewis, The Humanitarian Theory of Punishment, in CONTEMPORARY PUNISHMENT: Views, EXPlanATIONS, AND JustifiCATIONS 194, 195 (Rudolph J. Gerber \& Patrick D. McAnany eds., 1972).

159. Ezorsky, supra note 148, at xxii. Others argue, however, that desert can be either a moral (desert as a requital of evil for evil) or legal (desert as giving back an unfair advantage) concept. MOORE, supra note 141, at 77 .

160. Rawls, supra note 149 , at 84 .

161. MOORE, supra note 141 , at 77.

162. WALKER, supra note 139 , at 67.

163. PACKER, supra note 139, at 9. 
though unconscious, has a sense of dignity and demands the immolation of victims to avenge its injured amour proper. ${ }^{164}$

\section{Utilitarian Theories of Punishment}

The other three primary rationales for criminal punishment are utilitarian theories. The utilitarian view of punishment is that punishment always creates suffering, and suffering is always evil; there is no justification for suffering (and therefore, punishment) unless some secular good flows from that suffering. ${ }^{165}$ Punishment is justified only to the extent that it prevents or reduces the incidence of antisocial behavior. $^{166}$ If punishment creates a greater net secular good, punishment is just (even, some would argue, if the person being punished is innocent); if punishment does not create a greater net good for society, even the guilty should go free. ${ }^{167}$ Each of these theories-deterrence, incapacitation, and rehabilitation - will be discussed below. ${ }^{168}$

\section{a. Deterrence}

Deterrence can be defined as refraining from an action because of the perceived negative possible consequences of the action. ${ }^{169}$ Deterrence theorists argue that punishment is justified to the extent that it prevents future crime. While punishment may be an evil, good accrues through the prevention or reduction of the greater evil of crime. ${ }^{170}$ Deterrence "justifies penal coercion on the assumption that it contributes to order and stability in society by enforcing compliance with norms embodied in criminal law." 171 In the short-term, order is maintained by maximizing the effectiveness of punishment for potential criminals; in the long-term, punishment molds the behavior of, and reinforces morality for, future

164. H. Rashdall, Punishment and the Individual, in Philosophical Perspectives ON PUNISHMENT, supra note 148, at 64, 65.

165. PACKER, supra note 139 , at 11 .

166. Id.

167. MOORE, supra note 141, at 37.

168. Some have argued that two of these theories - general deterrence and incapacitation-are merely rationalizations for retribution. AM. FrIENDS SERV. COMM., supra note 139, at 58. Packer suggests that it is possible that all justifications for punishment are in truth fueled by vengeance. PACKER, supra note 139, at 59-60.

169. WALKER, supra note 139 , at 13 .

170. PACKER, supra note 139, at 39.

171. AM. FriendS SERV. COMM., supra note 139, at 49. 
generations. ${ }^{172}$ "[C]rime is prevented by the threat of unpleasant consequences"; the threat is reinforced by the punishment of those who commit crimes. ${ }^{173}$ Those consequences need not necessarily be physical; the threat of shame or social disgrace as a result of punishment may be sufficient to coerce compliance with the law. ${ }^{174}$

Jeremy Bentham explains that punishment, for deterrence theorists, has four objects: to prevent all offenses; to prevent the worst offenses, if offending is inevitable; to limit the offender to as little harm as possible; and to prevent that harm as cheaply as possible. ${ }^{175}$ Bentham's model

assumes a perfectly hedonistic, perfectly rational actor whose object it is to maximize pleasure and minimize pain. To such an actor contemplating the possibility of a criminal act the decision is based on a calculus: How much do I stand to gain by doing it? How much do I stand to lose if I am caught doing it? What are the chances of my getting away with it? What is the balance of gain and loss as discounted by the chance of apprehension? The purpose of criminal punishment, on this model, is to inject into the calculus a sufficient prospect of loss or pain to reduce to zero the attractiveness of the possible gain. ${ }^{176}$

Deterrence theory can be divided into two strains: special and general. Special deterrence theory argues that punishment is intended to prevent a person who has been punished from committing similar offenses in the future. ${ }^{177}$ "Once subjected to the pain of punishment . . . the individual is conditioned to avoid in the future conduct that he knows is likely to result again in the infliction of pain through punishment." General deterrence, in contrast, "is not concerned with the effects of punishment upon the subsequent career of someone who has been punished. It concentrates instead upon the efficacy of the threat of punishment upon those who are disposed to or tempted by crime."179 Punishment deters would-be offenders by showing them, through the

172. Id. at 49,58 .

173. Id. at 51 .

174. PACKER, supra note 139, at 42-43.

175. Jeremy Bentham, An Introduction to the Principles of Morals and Legislation 178 (Clarendon Press 1907) (1789).

176. PACKER, supra note 139 , at 40-41.

177. See TEN, supra note 144, at 7 ("Punishment deters the offender who is punished from committing similar offenses in the future ....").

178. PACKER, supra note 139, at 45.

179. AM. FriendS SERV. COMM., supra note 139, at 55. 
examples of others who have been punished, what they can expect to experience if they choose to do wrong. ${ }^{180}$

Punishment only acts as a deterrent when consistently applied, however. ${ }^{181}$ "A penal system that hopes to deter crime cannot tolerate exceptions." 182 If no punishment is meted out, "the deterrent effect of punishment breaks down, and subsequent punishments are wasted, as they inflict pain for no compensating return - a cruelty that cannot be justified." 183 Accordingly, "a legal system should not make exceptions to rules. Thus, the rules themselves must be humane, but the enforcement of those rules must be absolute." 184

At least one prominent retributivist scholar has come to believe that deterrence may provide a stronger justification for punishment than retribution. If moral theory is understood in the political context of the state, the state's goals for punishment should be paramount. And in the area of punishment, the state's overriding concern is with preventing future crime, not in addressing crime that has already occurred. Given that context, deterrence is arguably a more appropriate justification for punishment than retribution. ${ }^{185}$ Scholars have questioned whether as a practical matter, however, punishment actually serves this deterrent function. ${ }^{186}$

\section{b. Incapacitation}

"In a society that was single-mindedly devoted to the repression of crime as a paramount objective of social life, incapacitation would be the most immediately plausible utilitarian justification for the punishment of offenders." "187 Under this theory, punishment is justified because the incarceration of the offender prevents that person from committing further acts of harm, thus increasing the good to society. ${ }^{188}$ "To the hard-

\footnotetext{
180. TEN, supra note 144 , at 7 .

181. See RADZINOWICZ, supra note 140, at 122 (arguing that general deterrence is unlikely if laws are not adequately enforced).

182. MOORE, supra note 141 , at 38 .

183. Id.

184. Id. at 39 .

185. MURPHY, supra note 144, at 24.

186. See TEN, supra note 144 , at 8 (arguing that there is no evidence that punishment deters individuals). See generally Johannes Andenaes, Does Punishment Deter Crime?, 11 CRIM. L.Q. 76 (1968) (stating that it seems a majority of offenders react positively to punishment but there is a group of offenders who are not deterred).

187. PACKER, supra note 139, at 48.

188. See id. (contending that in a society concerned exclusively with repressing crime, incapacitation would be the most preferred justification).
} 
headed man in the street the utilitarian justification seems obvious. The longer a murderer, rapist, child-molester, or armed robber is detained the fewer the people he will victimize in the future: hopefully none." 189 That the criminal may not be either deterred or rehabilitated is immaterial to those justifying punishment on the theory of incapacitation; the benefits stem solely from the offender's inability to reoffend while "out of general social circulation."190 Incapacitation justifications rest on predictions that those who have committed crimes in the past are likely to commit additional crimes (of the same or different kinds) in the future. ${ }^{191}$ The "fact that a person has committed a crime . . . [serves] as [a] basis for assessing [that person's] personality and" forecasting the strong likelihood that the person will reoffend in some way. ${ }^{192}$

\section{c. Rehabilitation}

"The most immediately appealing justification for punishment is the claim that it may be used to prevent crime by so changing the personality of the offender that he will conform to the dictates of law ...." first half of the twentieth century, philosophers and reformers turned away from the idea of punishment as payback and looked to the behavioral sciences to remake offenders "into law-abiding citizens." 194 Rehabilitation inures to the benefit of both the criminal- " "in order to afford the means of amendment and to lead the transgressor to repentance, and to mercy""195 — and society. Rehabilitation treats each offender "as an individual whose special needs and problems must be" understood in order to effectuate positive change in that individual and must begin with an assessment of the offender's amenability to treatment. ${ }^{196}$ Rehabilitation can include inducement of repentance, recognition of moral guilt, and development of awareness of the demands of society via vocational training and psychological treatment. ${ }^{197}$ The intensity and duration of punishment depends upon the

\footnotetext{
189. WALKER, supra note 139 , at 38 .

190. TEN, supra note 144, at 8 . While Ten acknowledges that there are opportunities to commit crimes while in prison, he contends that "[those] opportunities are generally reduced." Id.

191. PACKER, supra note 139, at 49.

192. Id.

193. Id. at 53 .

194. MOORE, supra note 141, at 57.

195. Frances A. Allen, The Rehabilitative Ideal, in CONTEMPORARY PUNISHMENT: VIEwS, EXPLANATIONS, AND JUSTIFICATIONS, supra note 158, at 209, 210 (quoting GEORGE W. DALZELL, BENEFIT OF CLERGY AND RELATED MATTERS 13 (1955)).

196. PACKER, supra note 139, at 54.

197. HART, supra note 139, at 26.
} 
amount of effort needed to change the offender's personality. ${ }^{198}$ The offender is deemed rehabilitated when his values have changed sufficiently "that he will not commit similar offences in the future because he believes such offences to be wrong."199

Some proponents of rehabilitation measured the reformation of female offenders differently than that of men. William I. Thomas believed that criminal behavior in women was linked to their desire to experience the same kind of excitement as men. ${ }^{200}$ These "women who were unadjusted ... that is, women who wished for "freedom in the larger world'-were to be detained for indeterminate periods and psychologically adjusted to their original 'interest in human babies.",201

Rehabilitation was touted as a superior approach to criminal justice, improving the individual offender rather than inflicting the pain of punishment. "[W] hat could be more humane, more civilized, more sensible and more benevolent than directing society's efforts solely toward the end of achieving the rehabilitation or cure of that social misfit who breaks the law?" 202 Rehabilitation offered a number of benefits: saving the offender, protecting society by imprisoning the offender until the offender reformed, and "reduc[ing] the crime rate not only by using cure-or-detention to eliminate recidivism, but hopefully also by the identification of potential criminals in advance so that they can be rendered harmless by preventive treatment." 203 Proponents of rehabilitation stressed that they were not excusing the offender's behavior but directing society's resources in the manner most likely to result in the prevention of further criminal activity. ${ }^{204}$

Rehabilitation has its critics as well. Although proponents ask "how the reformatory view of punishment can be accused of disrespect for human personality," 205 critics argue that there is a legitimate moral question about whether society has a right to fundamentally change an offender's personality in order to compel him to become good, as well as a practical question about whether we know how to achieve that result. ${ }^{206}$ Rehabilitation, however well intended, still views the individual as

\footnotetext{
198. PACKER, supra note 139 , at 54.

199. TEN, supra note 144 , at $7-8$.

200. JONES, supra note 94 , at 7.

201. Id.

202. Richard Wasserstrom, Why Punish the Guilty, in PhILOSOPHICAL PersPeCtives ON PUNISHMENT, supra note 148, at 328, 328.

203. AM. FRIENDS SERV. COMM., supra note 139, at 37.

204. Wasserstrom, supra note 202, at 334.

205. Rashdall, supra note 164, at 65.

206. PACKER, supra note 139 , at 55-58.
} 
subordinate to society to the extent that the individual does not produce good for society. As Herbert Packer notes:

However benevolent the purpose of reform, however better off we expect its object to be, there is no blinking the fact that what we do to the offender in the name of reform is being done to him by compulsion and for our sake, not for his. Rehabilitation may be the most humane goal of punishment, but it is a goal of punishment so long as its invocation depends upon finding that an offense has been committed, and so long as its object is to prevent the commission of offenses. ${ }^{207}$

Others argue that rehabilitation undermines the general deterrent effect of punishment, subordinating the prevention of a first offense to the prevention of a future one by the same actor. ${ }^{208}$ Rehabilitation is also particularly susceptible to misuse. Because the length of sentence is tied directly to the time needed to reform the offender, individuals who were not declared "cured" languished for years in prisons, serving terms far exceeding what society now deems appropriate for those crimes. ${ }^{209}$ Jeffrie G. Murphy and Jules L. Coleman argue that rehabilitation no longer has any credence as a justification for punishment. They contend that a therapeutic regime can in fact be more harmful to the individual than imprisonment and can deny the individual due process. Additionally, they argue that psychiatrists are no more able than others to determine an individual's future dangerousness. Finally, they believe that treating a criminal as sick denies both the moral seriousness of the person's crimes as well as the personhood of the criminal. ${ }^{210}$

\section{B. Applying Theories of Punishment in State v. Shanahan}

Criminal punishment generally is justified under one or more of the four theories of punishment discussed above. But what happens when those theories are applied to an individual case-for instance, to the case of Dixie Shanahan?

\footnotetext{
207. Id. at 53-54.

208. HART, supra note 139, at 26-27.

209. See MOORE, supra note 141, at 66-72 (discussing the failures, injustices, and decline of the rehabilitation model).

210. MuRPHY \& COLEMAN, supra note 138, at 137-38.
} 


\section{Retribution}

The retributivist argument for punishing Dixie Shanahan might take the following forms: (1) criminal punishment is Dixie Shanahan's just desert for killing her husband; (2) punishing Dixie Shanahan equalizes the moral balance upset by her actions; (3) punishing Dixie Shanahan removes the unfair advantage she obtained by killing her husband.

First, consider the notion of just deserts in the context of this case. Historically, the idea of just desert was tied to the belief that the punishment should in some sense be proportionate to the crime; the lex talionis measure of an eye for an eye. ${ }^{211}$ Jeffrie G. Murphy asks, "[W]hat does it mean to say that a person deserves a certain level of suffering as punishment?" 212 For battered women who kill, what does it mean to deserve punishment when the victim of the ultimate crime has inflicted immeasurable damage on the person who finally kills him? Although Scott Shanahan never quite managed to kill Dixie, he certainly inflicted a great deal of injury, pain, anguish, and humiliation on her until just before the moment he died. Is it not fair to factor the suffering that Dixie Shanahan endured for nineteen years into the calculus of just deserts? Imagine a ledger in which Scott Shanahan's many crimes against his wife were tallied. Looking at all of the offenses for which Scott Shanahan was never punished (outside of six days in jail, which only led him to redouble his attacks on his wife), Dixie Shanahan's actions may have simply brought them to even on that balance sheet. For Dixie Shanahan's deserts to be just, her punishment should have been proportionate to her crime - the murder of an extremely abusive husband after a horrific episode of battering - not to the generic crime of seconddegree murder. A just punishment would have taken into account the years of abuse she endured, the abuse she faced over those two days in August, the danger posed to her and her unborn child, and her subjective belief that she would be killed before the end of that day. ${ }^{213}$ Because her

211. See supra text accompanying note 142 .

212. MURPHY, supra note 144, at 22.

213. North Carolina Supreme Court Justice Harry Martin made a similar argument in dissent in State v. Norman, 378 S.E.2d 8 (N.C. 1989). In considering Norman's self-defense claim, Martin stated,

By his barbaric conduct over the course of twenty years, J.T. Norman reduced the quality of the defendant's life to such an abysmal state that, given the opportunity to do so, the jury might well have found that she was justified in acting in self-defense for the preservation of her tragic life.

Id. at 21 (Martin, J., dissenting). 
punishment was divorced from the context in which her actions took place, she did not receive her just deserts.

Linked to the idea of just deserts is the belief that punishment equalizes the moral balance disturbed by the commission of a crime. Should an action still be punishable, though, when that action in some way restores the moral balance between the parties? Scott Shanahan's continual abuse of his wife surely placed him in moral debt to her. Scott Shanahan never repaid that moral debt; the six days that he spent in jail over a nineteen-year reign of terror hardly equalized the moral balance. Rather than upsetting the moral balance, Dixie Shanahan's act arguably restored some of the dignity and agency stolen from her as a result of years of abuse by her husband, and allowed her to escape from what promised to be many more years of abuse, had he not killed her sooner.

Moralistic retributivists believe that people deserve punishment when, by their crimes, they show themselves to be morally reprehensible; simply put, "[i]t is good when bad things happen to bad people.", ${ }^{214}$ Even accepting the prosecution's version of events, in which Dixie Shanahan shot her husband while he lay in bed during a lull in two days of abusing her, it is difficult to see how her crime renders her morally reprehensible. By all accounts, Dixie Shanahan was not a bad person, a morally reprehensible person. Witness after witness for both the prosecution and defense described her as a good mother, a person who cared for others both professionally and personally, and who endured year after year of horrific abuse in part because of her love for the mother of her abuser and in part because she continued to hope that Scott Shanahan could be a good husband and father. She had never been in trouble previously. She finally acted to save her own life and that of her unborn child. ${ }^{215}$ When a person is not wicked - for example, acting under duress - that person is not deserving of punishment. ${ }^{216}$ Dixie Shanahan's actions were unlawful, but she acted out of desperation, not wickedness. From a moralistic retributivist perspective, Dixie Shanahan did not deserve to be punished.

Did Dixie Shanahan derive some unfair advantage from her crime? Was she able to enjoy some greater liberty than others as a result of killing her husband? If so, legalistic retributivists would argue,

214. MOORE, supra note 141 , at 94, 108-09.

215. The prosecution introduced evidence about a bank account that Dixie Shanahan continued to draw on after Scott's death by forging his name on checks, apparently to establish a financial motive for the crime. Transcript of Trial, supra note 3, at 505-14. Though worse crimes have been committed for smaller sums of money, it is hard to believe that money was Dixie Shanahan's real motive, and the prosecution did not make much of this theory in its closing argument.

216. MOORE, supra note 141 , at 113 . 
punishing her is just. So what did Dixie Shanahan actually get as a result of her crime? Freedom from abuse. The ability to carry her unborn child to term. Safety for herself and her children. All of the benefits that Dixie Shanahan derived from her crime are taken for granted by most individuals in a free society. Legalistic retributivists believe that if a crime allows the actor to enjoy a wider liberty than others, punishment is justified to rectify that unearned advantage. ${ }^{217}$ But what if the crime simply restores the actor to the same state of liberty that others in the community enjoy? Scott Shanahan had deprived his wife of rights that most people probably never consciously consider - the right to dignity, the right to bodily integrity, the right to be free from violence. ${ }^{218}$ Killing him gave her no benefit not enjoyed by her neighbors. Dixie Shanahan killed to restore herself to the state in which members of her community routinely lived, free from fear and abuse. Achieving such parity can hardly be called an unfair advantage.

\section{Utilitarian Justifications}

Utilitarians would argue that Dixie Shanahan's punishment was just if punishing her created a greater societal good than refraining from punishment. Viewed through the specific lenses of deterrence, incapacitation, and rehabilitation, it is hard to see how punishing Dixie Shanahan serves the greater good.

\section{a. Deterrence}

Justifying Dixie Shanahan's punishment using deterrence theories raises two questions. Will the punishment prevent her from killing again? Will the punishment prevent others like her from killing? Because the answer to both of those questions is no, the punishment cannot be just.

217. Id. at 102 .

218. Such rights are guaranteed by international human rights declarations and laws including the Universal Declaration of Human Rights and the U.N. Declaration on the Elimination of Violence Against Women as well as by United States law. See generally CARRIE CUTHBERT ET AL., BatTered Mothers SPEAK OUt: A HuMAN Rights RePORT ON DOMESTIC ViOLENCE AND CHILD CUSTODY IN THE MASSACHUSETTS FAMILY COURTS (2002) (discussing human rights violations against battered women and children). 


\section{i. Special Deterrence}

One function of punishment, according to deterrence theorists, is to prevent the individual being punished from reoffending by showing that person that her wrongful actions will result in some form of deprivation. But if the offender is particularly unlikely either to recidivate or to be deterred because of the situation in which she finds herself, special deterrence is a weak justification for punishment.

Some believe that battered women are recidivists - that is, they tend to move from abusive relationship to abusive relationship. If this were true, a greater likelihood would exist that a battered woman who had killed her abuser would find herself in a position where she might kill again and punishment that deterred her from engaging in that behavior might be justified. But there is no empirical evidence to support the claim that battered women engage in serial abusive relationships, ${ }^{219}$ and there is no evidence that battered women who kill are likely to kill again. $^{220}$ Most battered women who kill, like Dixie Shanahan, have never been in trouble before. As Jean Harris noted,

It is one of the many ironies of this prison that many of the women with the longest terms are the least dangerous, and led the most useful lives before coming here. ... . They were good daughters, good wives, good mothers and good citizens until the day or night the final straw of cruelty was piled on top of all the other straws ....

Because battered women who kill are unlikely to be in a position to or be inclined to kill again, deterrence does not justify their punishment.

Legal philosophers have explored whether there are situations in which individuals will not be deterred by the threat of punishment. Nigel Walker contends that fear can make "normally law-abiding men and women become temporarily undeterrable and do things whose consequences would usually deter them."222 Walker further argues that homicides are "usually committed in undeterrable states of mind." 223 Herbert Packer adds that "[d] eterrence does not threaten those whose lot

219. WALKER, supra note 93 , at 7.

220. See supra text accompanying notes 93-95 (stating that battered women do not want to kill and will not do it if they do not absolutely have to).

221. JEAN HARris, “They AlWAys CALl Us LADIES”: StORIES From PRISON 219 (1988).

222. WALKER, supra note 139, at 14. Battered women kill out of fear rather than anger, although most battered women eventually feel anger toward their abusers. "If every battered woman who was angry were to kill her batterer, there'd be a lot more dead men around." WALKER, supra note 93 , at 201 .

223. WALKER, supra note 139 , at 16 . 
in life is already miserable beyond the point of hope."224 Dixie Shanahan's actions are consistent with these arguments. In her testimony, she described the fear that she felt for both herself and her unborn child, fear springing from the absolute certainty that she and the fetus would be dead by the end of the day, as her husband promised. ${ }^{225}$ She also described the relentless abuse, injury, and humiliation she suffered, ${ }^{226}$ an existence that would surely create the kind of hopelessness contemplated by Packer.

Before killing her husband, Dixie Shanahan was not thinking about the punishment she might endure for killing her husband; she was thinking about the punishment he would surely mete out if she took no action. Only afterwards did Dixie Shanahan realize that she was going to go to jail "[b]ecause I had just shot somebody.",227

Consider again the four questions Bentham posited that individuals ask when they consider committing a crime: "How much do I stand to gain by doing it? How much do I stand to lose if I am caught doing it? What are my chances of my getting away with it? What is the balance of gain and loss as discounted by the chance of apprehension?"228 Bentham believed that punishment operates to "reduce ... the attractiveness of the possible gain" by "inject[ing] into the calculus a sufficient prospect of loss or pain." 229 This model assumes an offender with the time, clarity of mind, and access to other options to make such a calculation. Dixie Shanahan never considered these questions, because the immediacy and dangerousness of her situation did not permit her to do so. ${ }^{230}$ The threat of punishment did not deter her from shooting Scott Shanahan and would not, in the extremely unlikely event that she found herself facing a similar situation, deter her in the future.

\footnotetext{
224. PACKER, supra note 139, at 45.

225. Transcript of Trial, supra note 3, at 489-90.

226. Id. at $443-89$.

227. Id. at 490 .

228. See supra text accompanying note 176 .

229. PACKER, supra note 139, at 41.

230. Some might argue that the jury rejected Dixie Shanahan's belief that she was in imminent danger of harm by finding that her actions were neither justified nor excused. But the failure to establish the elements of the legal claims of justification and/or excuse does not foreclose consideration of those beliefs; making a philosophical argument about the propriety of punishment is fundamentally different than establishing a legal claim. While the lull between the last beating and the shooting might have convinced the jury that the legal claims of justification and/or excuse were not available to Dixie Shanahan, that lull did not convince Dixie Shanahan that her life and the life of her unborn child were not in danger - the relevant standard in considering her claim on the justice of punishment.
} 


\section{ii. General Deterrence}

"Open a loophole for one woman to kill an abusive spouse and pretty soon you've got dozens of dead husbands." 231 This statement, made by an Iowa newspaper columnist shortly after Dixie Shanahan's sentencing, captures the general deterrence rationale for punishing battered women who kill. The theory of general deterrence is grounded in the assumption that potential offenders are deterred from committing crimes by their awareness of the punishment that others have received for committing the same offenses. ${ }^{232}$ Jurors relied on that rationale to convict Elaine Mullis, a battered woman who killed her husband with a four-inch paring knife as he choked and mauled her while she prepared dinner. ${ }^{233}$ After the trial, one juror explained the verdict: "We couldn't let her go . . . It would have been open season on husbands in Atkinson County.",234 Elaine Mullis was sentenced to life in prison. ${ }^{235}$

The idea that all women-not just battered women-will begin indiscriminately killing their husbands if battered women who kill are not punished drives the justification for punishing women like Dixie

231. David Yepsen, Op-Ed., Let Shanahan Case Run Course, Des Moines Reg., May 16, 2004, at 3 OP; see also JONES, supra note 94, at 289-90 (quoting a neighbor of Francine Hughes who had once pulled her husband off of her when he was beating her in the yard, stating, "If she gets out of this ... there'll be a lot of dead guys lying around.").

232. For punishment to have a deterrent effect, the fear of punishment must be greater than the sacrifice involved in refraining from the offense. Andenaes, supra note 186, at 79 ("If we make the risk of punishment sufficient to outweigh the prospect of the gain, the potential lawbreaker will, as a rational man, choose to stay within the limits of the law."). But what if the punishment actually provides a respite from the conditions that lead to the crime? One woman serving life in prison for killing her batterer stated, "It's better than the hell I lived with .... . There are rules here, every day's predictable. I don't worry anymore about doing something wrong to make him angry. You can't imagine what a relief that is. I feel better now. At least I know what to expect." WALKER, supra note 93 , at 224.

233. JONES, supra note 94, at 324. Elaine Mullis was using the paring knife to prepare dinner when her husband attacked her. The wound in his chest caused by the knife needed only four stitches, but because the blade struck an artery and the medical care her husband received was "delayed and inadequate," Connie Mullis died. Id.

234. Id.; see also id. at 290 (citing a 1978 NEWSWEEK article, Wives Who Batter Back, in which the author worried that if battered women were not punished for killing their abusers, such "frontier justice" would create "a new legitimacy for violent retaliation"). Jones notes that the media created the impression that women were routinely murdering their husbands and getting away with it by reporting only the acquittals. Id . at 292 . In fact, the work done by battered women's advocates to increase resources and options for battered women has actually saved the lives of a number of men; "from 1976 through 1987 the number of women killing male partners decreased by twenty-five percent." Id. at 346; see also Angela Browne \& Kirk R. Williams, Exploring the Effect of Resource Availability and the Likelihood of Female-Perpetrated Homicides, 23 LAW \& SOC'Y REV. 75, 91 (1989) (explaining that states with better legislation and resources had lower rates of homicides by women against their male partners).

235. JONES, supra note 94, at 324. 
Shanahan. But just as it is doubtful that Dixie Shanahan would have been deterred from her crime, it is also doubtful that other women in the same position would be deterred by knowing that she was punished. Deterrent effects have been linked to a number of variables, including "the type of crime, ... the incentive to commit the crime, the severity of the threatened punishment and the extent to which the penalty is known [to the offender], and the likelihood of being caught and punished."236 Legal philosophers believe that some crimes cannot be deterred, regardless of the severity of the penalty. ${ }^{237}$

Deterrence assumes that the potential offender has options other than committing the crime and can therefore make a reasoned choice not to offend. But the context in which battered women make decisions about offending is often one in which no other options are available. For battered women who kill, the incentive is often to save their own lives or the lives of their children, and though they may be aware of the penalties, they often believe that no other option is available to them, particularly because most kill after "numerous other efforts to fight back, escape, or appease the abuser [have] failed." 238 Battered women are frequently isolated from both formal and informal sources of help - the legal system, shelters, clergy, family, and friends. ${ }^{239}$ Even if the woman is able to reach out, services may be inaccessible for any number of reasons, including location, language, or culture. Further, although services that purport to stop the violence may be available, they might not be particularly effective. Battered women who ultimately kill are aware of the stories of women who have done everything "right" - called the police, sought protective orders, cooperated with prosecutors-only to be horribly abused or killed by their attackers. ${ }^{240}$ Which is likely to have a greater effect-seeing battered women who kill go to prison, or

236. AM. FRIENDS SERV. COMM., supra note 139, at 56.

237. See id. at 58 ("There is a class of offenders whose crimes cannot be prevented no matter how harsh the threatened penalty."). This argument assumes, of course, that deterrence works to prevent some crimes, a claim which has been hotly disputed in the literature. See Andenaes, supra note 186 , at $79,92-93$ (stating extreme positions appear from the literature and concluding that "the majority of offenders react positively to punishment but that there remains a hard core of offenders who are neither reformed nor deterred").

238. GAGNÉ, supra note 18 , at 176 .

239. See id. at 19 ("Abusers often attempt to control and isolate victims in an effort to guard the secret of abuse and because of their jealousy of any attention their partners may give or receive from family, friends, or coworkers.").

240. See, e.g., Cuniberti, supra note 98 (reporting how her husband shot Kelli Alexander after Kelli called the police, left her husband, and obtained a restraining order); see also Moore v. Green, 848 N.E.2d 1015, 1018-27 (Ill. 2006) (denying immunity to police officers who responded to 911 call from victim who had an emergency protective order by driving to her home but failing to enter and investigate; five minutes after the police left, she was killed by her abuser). 
seeing women who have done all the system asked of them harmed, even killed, despite their best attempts to flee? ${ }^{241}$ The lack of meaningful alternatives for battered women whose situations have grown so dire that they believe they must kill or be killed impairs their ability to be deterred.

Deterrence is also grounded in the idea that the potential offender will assess her own position relative to the experiences of others like her. But the experience of being battered is not necessarily generalizable. In the midst of a battering incident, the victim is thinking only about the unique circumstances of her situation, assessing the lethality of her attacker and the likelihood that she or someone close to her will be killed. It is unlikely that battered women assimilating their perceptions of imminent death stop to think, "Dixie Shanahan killed her husband and was sentenced to fifty years of imprisonment. My situation is like hers. I am likely to be sentenced similarly. Therefore, I should find another solution-before he kills me." Arguably, the deterrent effect could operate at an earlier moment in the relationship, spurring the woman to leave or seek other assistance with her abuser. That argument assumes that the decision to kill is made at that earlier point; studies of battered women who kill suggest, however, that these decisions are situational, made in the midst of a battering incident. ${ }^{242}$ Thinking about how she will not be there to raise her children is not likely to deter the battered woman who kills if she is certain that she or that child is about to die.

Killing her abuser is the battered woman's only recourse in an untenable situation. She believes she must kill or be killed. Knowing that Dixie Shanahan has been punished will not deter her from saving her own life. ${ }^{243}$ General deterrence is not an adequate rationale for punishing Dixie Shanahan.

241. Deterrence theorists have noted that general deterrence is unlikely if enforcement of the law is inadequate. See RADZINOWICZ, supra note 140, at 122 ("Neither fear of punishment nor respect for the law is likely to hold back potential offenders effectively if [enforcement of the law] is known to be inadequate."). Given the uneven enforcement of laws meant to protect battered women, batterers are arguably not being deterred at all. The criminal system is far more efficient at convicting and punishing battered women who fight back against their abusers. See BROWNE, supra note 31, at 11 ("FBI statistics indicate that fewer men are charged with first- or second-degree murder for killing a woman they have known than are women who kill a man they have known."); see also Meg Crager et al., King County Coal. Against Domestic Violence, VictimDefendants: An EMERging Challenge in Responding to Domestic Violence in SEATtle AND THE KING COUNTY REGION 16 (2003) ("[T] he information available suggests that there is a significant and increasing number of domestic violence survivors being arrested and/or charged with domestic violence-related crimes in the King County region.").

242. See supra note 110 and accompanying text.

243. Of course, to the extent that she is proven correct when she is killed, it is impossible to know whether a dead battered woman was deterred by the thought of punishment. 


\section{b. Incapacitation}

Punishing Dixie Shanahan certainly means that she will be kept out of society. The relevant question is whether keeping her out of society either protects society or promotes societal good, as required by utilitarianism.

Justifying punishment through incapacitation assumes that because an individual has offended in the past, she is likely to commit additional crimes; the community, therefore, will be safer if the individual is removed from society. ${ }^{244}$ If the offender is unlikely to recidivate, however, the justification fails. Murderers have very low rates of recidivism, ${ }^{245}$ and, as discussed above, battered women who kill have rarely engaged in criminal activity previously and are highly unlikely to commit future crimes. ${ }^{246}$ While incapacitating Dixie Shanahan will certainly keep her out of society, it is doubtful that doing so prevents future crime.

A more interesting question is whether the greater good accrues to society as a result of punishing Dixie Shanahan. By all accounts, Ms. Shanahan was a productive member of her community. She provided care not only for her three children and for her husband's parents until their deaths, but also for the sick and elderly patients residing in the nursing homes where she worked throughout her marriage. ${ }^{247}$ Proponents of incapacitation would argue that society benefits because Ms. Shanahan is not free to commit other crimes. But the likelihood of Ms. Shanahan's reoffending is low and must be balanced against a number of other costs to society created by incapacitating her. Instead of having Ms. Shanahan contribute to the community's tax base, the state will bear the costs of her incarceration for at least the next thirty-five years. Ms. Shanahan's children lose their mother, the only stable figure in their lives. Experts believe that severing the bonds between children exposed to domestic violence and their abused parents can have profoundly negative consequences for those children. ${ }^{248}$ Ms. Shanahan's

244. PACKER, supra note 139 , at 49.

245. Id. at 52-53.

246. Battered women who kill are unlikely to recidivate not just because they avoid future abusive relationships, but because they may avoid relationships altogether. As Joyce DeVillez, who hired a hit man to kill her husband after twenty-three years of abuse, noted, "If I ever get out of here, ... I'll never have a man around the house again." JONES, supra note 94, at 323-24.

247. Transcript of Trial, supra note 3, at 449.

248. See Nicholson v. Williams, 203 F. Supp. 2d 153, 197-200 (E.D.N.Y. 2002) (reviewing the testimony of a number of experts on the impact of domestic violence on children, including Dr. Evan Stark, Dr. Jeffrey Edleson, Dr. David Pelcovitz, Dr. Peter Wolf, and Betsy McAlister Groves). For a 
new husband, friends, neighbors, coworkers, and community are all deprived of the positive contributions she made to their lives on a daily basis. Ms. Shanahan's elderly and disabled patients no longer receive the high quality of care she provided them. Juxtaposing all of these losses to the community against the low risk of further criminal behavior, it is hard to see the utilitarian justification for incapacitation in this case.

\section{c. Rehabilitation}

Will punishment rehabilitate Dixie Shanahan? That question assumes that Ms. Shanahan is somehow in need of rehabilitation, an assumption based on the notion of criminals as diseased rather than depraved. While the rehabilitation justification for punishment has fallen out of vogue in recent years, legal doctrines developed specifically to protect battered women could, in fact, inadvertently provide support for the idea that battered women need rehabilitation.

Recognizing that the failure of courts to admit evidence of battering prevented them from presenting persuasive self-defense cases, advocates for battered women fought to have this evidence admitted in the trials of battered women who killed. ${ }^{249}$ Experts were permitted to testify to the effects battering has on women and how that battering created the context for the actions taken by battered women who killed. ${ }^{250}$ This evidence on the effects of domestic violence has come to be known as "battered woman syndrome.", ${ }^{251}$ As Elizabeth Schneider notes, "Because the term is frequently used as shorthand for "evidence of a battering relationship' by judges, legislators, and legal scholars, it is not clear in any particular context what it refers to." 252 What it suggests, however, is that all battered women suffer from some disease or syndrome which can be cured. Schneider argues that "because 'battered woman syndrome' sounds like a form of mental disease or defect, lawyers relying on this framework are more likely to view the case through the lens of an impaired mental state." 253 The term "implies that [the battered woman] is limited because of her weakness and her problems."254 Judges and

discussion of the impact of parental incarceration on children, see generally Elizabeth I. Johnson, Youth with Incarcerated Parents: An Introduction to the Issues, PREVENTION RESEARCHER, Apr. 2006 , at 3.

249. ElizABeth M. SCHNEIDER, BATtered WOMEN AND FEMinist LAWMAKING 119 (2000).

250. Id.

251. Id. at 123 .

252. Id.

253. Id. at 124 .

254. Id. at 135. Battered woman syndrome has also been criticized for inappropriately 
juries hearing such evidence may make similar assumptions, triggering the rehabilitation justification for punishment: punishment is appropriate in these cases because the battered woman suffers from a condition that must be cured before she can safely resume her place in society.

The problem with this rationale, of course, is that the term "battered woman syndrome" has been horribly misconstrued. While some battered women are mentally ill, ${ }^{255}$ the condition of being battered does not, in and of itself, constitute a mental illness or defect. ${ }^{256}$ A battered woman who kills cannot be cured of being a battered woman through punishment - nor does she need to be.

Rehabilitation also assumes that the criminal cannot or does not recognize the wrongfulness of her actions. ${ }^{257}$ But most battered women who kill regret the killings and recognize their own legal guilt. ${ }^{258}$ They do ask, however, that these killings be considered in the context of the violence that they suffered. ${ }^{259}$ As one woman explained,

I'm not asking to be found not guilty, because I am guilty, I took his life, I did it. But, there were extenuating circumstances, and they should take that into consideration, you know. . . . I am definitely guilty of taking his life, I mean, if I was found not guilty, they'd have to look for who did it, right, I mean, someone's got to be guilty. And I certainly take responsibility for what I did, I have no problem with that, but I certainly don't deserve 18 to 20 years for it. ${ }^{260}$

C.L. Ten explains that offenders are rehabilitated to the extent that they will not commit similar offenses in the future because their values have changed and they now believe such offenses are wrong. ${ }^{261}$ Most battered women who kill already have this understanding, but if faced

reinforcing stereotypes of battered women as passive victims. This characterization is particularly problematic for battered women who kill because "it fails to account for why they eventually acted. Jurors are presented with a description of the battered woman who is helpless and submissive. Any woman who deviates from the model, who seeks help or defends her own life may be seen as abnormal or unreasonable." BUSCH, supra note 95, at 40.

255. See generally Carole Warshaw \& Holly Barnes, The Domestic Violence \& Mental Health Policy Initiative, Domestic Violence, Mental Health \& Trauma: RESEARCH HIGHLIGHTS, available at http://www.vawnet.org/DomesticViolence/Research/ otherpubs/MentalHealthResearch.pdf (surveying research regarding the correlation between domestic violence and mental health).

256. Kinports, supra note 3 , at 170

257. See supra text accompanying note 199 (stating that an offender is rehabilitated when he believes his offenses to be wrong).

258. See, e.g., BUSCH, supra note 95 , at 66 (describing the feelings of a woman convicted for murdering her husband).

259. Id.

260. Id.

261. TEN, supra note 144 , at $7-8$. 
with the same situation would likely make the same decision, believing that they had no other choice. As Dixie Shanahan explained shortly after her sentencing, "If I was in the same circumstances, would I do it again? Yes I would . . . knowing what it cost me and my children."262 These women need no change in values - only a change in the circumstances that created a situation that led them to kill.

Neither retributive nor utilitarian theories of justice justify the punishment Dixie Shanahan received for killing her husband. The utilitarian theories, as discussed above, cannot be justly applied to the case of Dixie Shanahan, or indeed, to the cases of most battered women who kill. Punishment could be justified under a retributivist theory, but only to the extent that Dixie Shanahan received her just deserts. Because the punishment was not imposed with an eye toward the abuse she had suffered or the context for her actions, the punishment of Dixie Shanahan was not just.

What precludes Dixie Shanahan and other battered women who kill from receiving their just deserts? Three factors spur the unjust sentences in these cases: mandatory minimum sentence requirements, judicial unwillingness to consider context, and concerns about the failure to punish these women harshly.

\section{Justice Denied: Why BATTERED WOMEN RECEIVE UNJUST PUNISHMENTS}

\section{A. Mandatory Minimum Sentences}

Conceding that Dixie Shanahan was guilty of second-degree murder, retributivist theories justify some kind of punishment. But her sentence - fifty years to life, with a minimum term of imprisonment of thirty-five years - was not justified. This inequity is a result of the mandatory minimum sentence Judge Smith was required to impose in her case. Mandatory minimum sentences preclude judges from ordering appropriate punishment when punishment is due. The inability to exercise discretion in sentencing defeated the just application of the theories of criminal punishment in the case of Dixie Shanahan.

262. Staci Hupp, Shanahan Says She Would Do It Again, Des MoInes REg., May 13, 2004, at $1 \mathrm{~A}$. 


\section{Mandatory Minimums in Iowa}

The mandatory minimum sentence in Iowa for second-degree murder is fifty years of imprisonment. ${ }^{263}$ An offender must serve at least seventy percent of her sentence before becoming eligible for parole. ${ }^{264}$ Mandatory minimum sentences in Iowa have withstood constitutional challenges that the sentences deny equal protection of the law or amount to cruel and unusual punishment. ${ }^{265}$

\section{Women and Mandatory Minimums}

Mandatory minimum sentences remove judicial discretion from sentencing determinations, ensuring that every person convicted of a particular crime serves the same amount of time for the offense. ${ }^{266}$ One goal of these sentencing reforms was to create gender equality in sentencing. ${ }^{267}$ For women, however, the move to mandatory minimum sentences has been particularly problematic, for judges are no longer able to consider the contexts in which these women's crimes take place. In cases involving drug crimes, that has meant that women who were marginally involved in the drug trade because of their relationships with high-level drug dealers have been sentenced to long prison terms-in some cases, terms longer than those received by their much more culpable mates. ${ }^{268}$ Courts have been unable to weigh the nature of the

263. IOWA CODE ANN. $\$ \$ 707.3,907.11$ (West 2003).

264. Iowa CoDE ANN. $\S 902.12$ (West Supp. 2006). Until 2003, Iowa law required an offender to serve eighty-five percent of her sentence prior to becoming eligible for parole. In Dixie Shanahan's case, that means a seven-year difference in the length of her sentence. The old Iowa law was strongly influenced by requirements placed on funding available to the states through the federal Violent Offender Incarceration/Truth in Sentencing Act. Iowa LegisLative SERVS. Agency FisCAL SERVS., REVIEW OF IOWA's 85.0\% SENTENCING LAW 1 (2003). Once that funding was eliminated, Iowa no longer had a "financial incentive[] to maintain the $85.0 \%$ sentencing law." Id. at 3.

265. State v. Holmes, 276 N.W.2d 823, 829 (Iowa 1979).

266. Philip Oliss, Comment, Mandatory Minimum Sentencing: Discretion, the Safety Valve, and the Sentencing Guidelines, 63 U. CIN. L. REV. 1851, 1851 (1995). Mandatory minimum sentences were seen by some as a means of addressing gender and race inequity in sentencing. Shimica Gaskins, "Women of Circumstance"-The Effects of Mandatory Minimum Sentencing on Women Minimally Involved in Drug Crimes, 41 AM. CRIM. L. REV. 1533, 1539 (2004); Oliss, supra, at $1852-53$.

267. Myrna S. Raeder, The Forgotten Offender: The Effect of the Sentencing Guidelines and Mandatory Minimums on Women and Their Children, 8 FED. SENT'G REP. 157, 157 (1995). This desire to enforce gender parity in sentencing is arguably a backlash against feminism. "As lawenforcement officials repeatedly told criminologist Rita Simon: 'If it's equality these women want, we'll see that they get it." JONES, supra note 94, at 4.

268. See generally Gaskins, supra note 266 (examining how mandatory minimum sentencing affects women who were minimally involved in the commission of a drug crime). 
woman's involvement, factors mitigating her responsibility (for example, physical abuse by the dealer coercing the woman's involvement), or the woman's status as a mother or caregiver. ${ }^{269}$

Battered women who kill face an analogous problem. Confronted with mandatory minimum sentencing laws, battered women who choose to take their chances at trial know that if convicted, judges will be unable to factor the abuse that they have suffered-both over time and immediately before the crime-into sentencing determinations. ${ }^{270}$ Judges are not able to consider the children and families left behind when these mothers are incarcerated for long prison terms. They are not permitted to factor in the previously spotless criminal records of the offenders and the contributions those women made to their communities. ${ }^{271}$ And, as described above, much of this information is important in determining the justice of a sentence under the prevailing theories of punishment. Retributive goals are not met if the sentence meted out gives an offender far more time than she deserves, given the context in which she acted. Judges cannot weigh the good to society a particular sentence would create if the judge has no options in sentencing. Without some discretion, judges are unable to do justice.

\section{Mandatory Minimums and State v. Shanahan}

This is precisely what happened in State v. Shanahan. Dixie Shanahan turned down a plea bargain that could have resulted in her release in as little as four years. ${ }^{272}$ Instead, she chose to tell her story to the jury; the jury rejected her self-defense claim, believing that her

269. Id. at 1541. In a recent Supreme Court oral argument, Justice Scalia suggested that women who are coerced into crime have a choice - they could shoot their abusers rather than participate in their crimes. Scalia joked, "I'd just wound him." Gina Holland, Justices Weigh Abuse in Woman's Defense, Associated PRESS, Apr. 25, 2006, available at http://www.ncdsv.org/images/ JusticesWeighAbuseinWomanDefense.pdf.

270. The ability to consider that information can make a tremendous difference. For example, when Laura Rogers pled guilty to manslaughter after killing her husband, who had battered her and videotaped his rape and impregnation of her daughter, Judge Paul A. Hackner factored expert testimony about battered spouse syndrome into his decision to sentence her to ten years in prison but to suspend all but the time she had served. Rogers was released from prison that day. Eric Rich, Judge Frees Killer of 'Horrible' Husband, WASH. POST, Nov. 10, 2004, at B1.

271. As the Honorable J. Spencer Letts explained, "Indeed, under this sledgehammer approach, it could make no difference if the day before making this one slip in an otherwise unblemished life the defendant had rescued 15 children from a burning building or had won the Congressional Medal of Honor while defending his country." Gaskins, supra note 266, at 1543 (quoting FAMILIES Against Mandatory Minimums, MANDATORY SENTENCING WAS ONCE AMERICA's LAW-ANDORDER PANACEA. HERE'S Why IT'S NOT WORKING 5 (1998)).

272. Leonard Pitts Jr., Op-Ed., Sentencing Rules Ignore Common Sense, KAN. City StaR, June 8,2004 , at B7. 
husband had been asleep, and therefore not an imminent threat to her when she shot him. ${ }^{273}$ Because under Iowa law they could not be told the penalties for the various crimes they were considering, some members of the jury believed that the second-degree murder verdict would result in a sentence of twenty-five years, and that Shanahan would be released in eight. ${ }^{274}$ At least one juror believed the abuse Dixie Shanahan suffered should have been factored into her sentence. ${ }^{275}$

But that choice was not available to Judge Smith. As he told Dixie Shanahan at her sentencing, "[T]his Court has no option but to sentence you to prison for the indeterminate term of not to exceed 50 years.",276 Smith continued,

[I]t needs to be said that the mandatory minimum sentencing structure that has been imposed on this court throughout the State of Iowa for this type of offense is, in my opinion, wrong. It may be legal but it is wrong. ...

... By imposing mandatory minimums as severe as this one in this case, a legislature from 15 years ago is, in effect, sentencing you, knowing nothing about this case, without trusting the good judgment of the judge in the case and without trusting the good judgment of the Board of Parole that might consider your case sooner than they will.

Perhaps, Dixie, your case will make the legislature, which is made up of good people dedicated to public service, take notice and do something to untie the hands of the judges in this state and the Parole Board in this state. I hope so and I know your friends and you do as well.

However, at this time, as your attorney has said, I have no other options. ...

The reason for this sentence is the term of the statute-I'm sorry. ${ }^{277}$

Judge Smith knew that justice had not been done in this case. So did many in the community that was ostensibly being kept safe by

273. Hupp, supra note 5.

274. Susan A. Benson-Blaine, Juror: I Wouldn't Change Verdict, But Sentence Extreme, DES MOINES REG., May 25, 2004, at 7A.

275. Id.

276. Transcript of Sentencing, supra note 8, at 6 .

277. Id. at $8-10$. 
incarcerating Dixie Shanahan. One woman shared her story in a letter to the editor of the Des Moines Register:

I am appalled she was convicted and sentenced so harshly. If you have not been in her position, you cannot know the feeling of helplessness that would drive you to protect yourself and your children by such desperate means.

Twenty-four years ago I, too, held a gun to the head of my abuser as he slept. The only reason I did not pull that trigger is because my infant daughter woke up and cried.

As Rekha Basu of the Des Moines Register concluded about the Shanahan case, "There are cases where the law is followed to the letter, but you'd be hard-pressed to conclude that justice was served."279

Shanahan's friends and attorney have asked Iowa governor Tom Vilsack for a pardon. Three jurors signed a letter to the governor on her behalf, stating, "WWe would wholeheartedly support a decision on your part to reduce Dixie Shanahan's sentence." 280 In January 2007, Vilsack responded to these entreaties by partially commuting her sentencedecreasing the time she was required to serve from thirty-five years to ten before she is eligible for parole. ${ }^{281}$ But the commutation fails to address the underlying problem faced by Dixie Shanahan and other battered women who kill. Dixie Shanahan did not receive a just sentence because Judge Smith was unable to sentence her as an individual-as a mother, as a member of the community, as a battered woman who had endured nineteen years of horrific abuse. The Des Moines Register opined, "In an ideal world, the judge would have established a sentence based on a detailed assessment of the facts of Shanahan's case, her

278. Sherie Vermeer, Letter to the Editor, Have the Courage to Pardon Shanahan, DES MoINES REG., June 8, 2004, at 8A; see also Letter to the Editor, Shanahan Punished by Husband and State, Des MoINes ReG., May 5, 2004, at 14A (publishing multiple letters to the editor arguing that Shanahan's sentence was unfair).

279. Rekha Basu, Op-Ed., Dixie Shanahan Verdict: Where's the Justice?, Des MoINES ReG., May 5, 2004, at 15A; see also Editorial, Tying Justice's Hands, OMAHA WORLD-HERALD, May 12, 2004, at 6B ("Nothing can negate Shanahan's responsibility for her actions; we simply mean to point out that justice in this case is not a simple mathematical formula. . . But in Iowa's judicial system, there was no room for weighing those gray areas of justice. That's because of mandatory sentencing laws.”). But see Yepsen, supra note 231 (arguing against weakening mandatory minimum sentences in wake of the Shanahan verdict).

280. Hupp, supra note 4.

281. Ferak, supra note 4. Iowa's Board of Parole previously denied her request for early release. Bert Dalmer, Parole Board Says Dixie Duty Will Stay In Prison, Des MoInes Reg, July 28, 2006, http://www.desmoinesregister.com/apps/pbcs.dll/article?AID=/20060728/NEWS01/60728014/1001/ RSS01 
record and potential for future criminal trouble based on expert testimony." Instead, because of mandatory minimum sentencing, "The sentence is the same, whether one is guilty of a pointless murder in the commission of a crime or a tortured woman who withstood unspeakable abuse from her husband before she finally snapped and did something she would never be in a position to do again.",282

\section{The Case of Nancy Seaman}

Nancy Seaman was a devout Catholic, a mother, a fourth-grade teacher, and a victim of domestic violence. On May 10, 2004, Seaman killed her husband, Robert, after he cut her with a knife and threatened her life - the culmination of thirty years of abuse. Seaman grabbed an axe and hacked her husband to death, then cleaned up the mess and kept his body wrapped in a tarp in her car for three days. Seaman was found guilty of first-degree murder. ${ }^{283}$ At sentencing, Judge John J. McDonald told Seaman that he "didn't doubt for a minute" that she had been abused and urged her to share her story with other battered women so that they would seek help before being faced with a situation like Seaman's, then sentenced her. ${ }^{284}$ "'I have no choice but to sentence you to mandatory life in prison ... I wish you luck." ${ }^{285}$ What justification exists for incarcerating women like Nancy Seaman and Dixie Shanahan for the rest of their lives?

\section{Mandatory Minimums Undermine the Justice of Punishment}

Because the judges in the Shanahan and Seaman cases had no discretion in sentencing, there was no justice for these women. Having been found guilty of second-degree murder, Dixie Shanahan deserved some sort of punishment. From a retributivist perspective, she should have been given her just deserts. From a utilitarian perspective, she should have received a punishment that created a greater good for society. Dixie Shanahan's punishment did neither. The mandatory minimum sentence meant that Judge Smith could not consider what just deserts would mean for Dixie Shanahan, a battered woman who killed her long-time abuser in order to save her unborn child. Instead, Dixie Shanahan received the same deserts as every other offender convicted of

282. Editorial, Bring Sense to Sentencing, Des MoINES Reg., May 4, 2004, at 10A.

283. Mike Martindale, Jury Doesn't Buy Seaman's Story, Detroit News, Dec. 15, 2004, at 1A.

284. Mike Martindale, Seaman Gets Life in Prison, Detroit News, Jan. 25, 2005, at 1B.

285. Id. 
second-degree murder - those with no prior histories with their victims, those with lengthy criminal records, those who did not have any reason to believe that their lives were in danger. For deserts to be just, they must be individualized; retributivists believe that no two punishments should be the same. Mandatory sentencing precludes judges from engaging in that type of analysis.

Mandatory sentences also prevent judges from weighing the costs and benefits of incarcerating a particular individual. Judge Smith could not consider whether some other punishment - for example, requiring that Dixie Shanahan work on behalf of other battered victims and share her story with victims and abusers - would be more likely than incarceration to deter other battered women from killing their spouses. He could not determine whether incapacitating Dixie Shanahan would inure to the benefit of society by preventing future crime. He could not weigh the costs of incarcerating Dixie Shanahan - financial, social, and personal-against the benefits to society of some other sentence.

The justice of punishment is intimately tied to understanding the individual offender and examining the context for that offender's actions. Without discretion to consider anything other than the crime itself, judges cannot develop punishments that are just from either a retributivist or a utilitarian perspective. Mandatory minimums undermine the justifications for criminal punishment and result in unjust punishments - as they did in the case of Dixie Shanahan.

The judges in the Shanahan and Seaman cases recognized the fundamental injustice of sentencing these women to long prison terms, but were shackled by state mandatory minimum sentencing requirements. But in many other jurisdictions, there are no such requirements. What explains the imposition of unjust sentences in cases involving battered women who kill in these states?

\section{B. Judicial Unwillingness to Consider Context}

Judicial discretion is a necessary, but not sufficient, element in establishing just punishments. If judges have the discretion to consider the context in which battered women kill, but refuse to do so, that refusal undermines the justice of punishment just as effectively as being fettered by mandatory minimum laws.

Judges can foreclose the introduction of context into sentencing in two ways. They can block the introduction of evidence on domestic violence in the cases of battered women who kill. In the alternative, they can admit such evidence but dismiss it because they do not believe that the battered woman's claims are credible or relevant to sentencing. 
Since courts and legislatures paved the way for the introduction of evidence on battered women's syndrome in the cases of battered women who killed their abusers, pretrial battles about whether defendants can present expert testimony on the applicability of the syndrome to their own situations have become common. Prosecutors routinely argue that the defendant does not fit the stereotype of the battered woman described by the syndrome; defense attorneys argue that the syndrome does not describe a prototypical victim, but rather a set of behaviors and reactions that are common to women who have been abused. ${ }^{286}$ The verdict in the case of a battered woman who kills is profoundly affected by her ability to bring such evidence before the court; that evidence provides the context necessary to understand the woman's perceptions, experiences, and choices.

The decision to exclude such evidence can have a substantial impact on the justice of punishment as well. Kathy Thomas shot her boyfriend, Reuben Daniels, after Reuben began to severely beat her (not for the first time) while she made dinner. ${ }^{287}$ Reuben pushed Kathy from the kitchen onto the living room couch, where she found his gun, picked it up and shot him. ${ }^{288}$ At trial, the judge refused to allow two experts to testify about battered woman syndrome. ${ }^{289}$ Kathy Thomas was convicted of first-degree murder and sentenced to fifteen years to life. ${ }^{290}$

Would hearing evidence about how enduring four years of repeated severe beatings affected Kathy Thomas's perception of the danger she faced have changed the outcome of her case? That question cannot be answered definitively, but it is fair to say that hearing such evidence might have convinced the judge that a lighter sentence was appropriate. Barring evidence about past abuse and the effects of that abuse prevents the judge from understanding why the battered woman acted as she did, and therefore crafting a sentence tailored to her individual crime. When

286. Of course, charging decisions are crucial as well. As one commentator noted, "[P]rosecutors are likely to bring charges even when they believe the equities favor a reduced sentence. Suffolk County, New York, district attorney James M. Catterson, Jr., stated, 'When you have a life taken, there has to be some punishment. But it may be punishment with sensitivity and understanding.", Alison M. Madden, Clemency for Battered Women Who Kill Their Abusers: Finding a Just Forum, 4 HASTINGS WoMEN'S L.J. 1, 35 (1993). The problem, of course, is that judges sometimes cannot or will not punish with sensitivity or understanding, as discussed in Part V.B.

287. Linda L. Ammons, Discretionary Justice: A Legal and Policy Analysis of a Governor's Use of the Clemency Power in the Cases of Incarcerated Battered Women, 3 J.L. \& POL'Y 1, 10 (1994).

288. Id.

289. Id.

290. Id. 
sentences are divorced from the experiences of the individual offender, the justice of punishment is undermined.

Given changes in the law, as well as a growing awareness of the value of testimony on battered women's experiences of violence, judges are less likely than in the past to prevent such evidence from coming in altogether. Equally damaging to the battered woman's attempt to obtain a just sentence, however, is a judge's unwillingness to factor the abuse she has suffered into her sentence. Consider, for example, the case of Kosal Pang, who pled guilty to third-degree murder in the death of her husband. ${ }^{291}$ Pang and her three children all described the abuse they endured at the hands of Sokhan Sao. Their children testified that Sao kicked, hit, and dragged Pang by the hair. ${ }^{292}$ On one occasion, Sao threw boiling soup in Pang's face, injuring her eye. ${ }^{293}$ Sao pistol-whipped his son for being late to school. ${ }^{294}$ Pang, a Cambodian refugee, distrusted the government and would not ask police for help. ${ }^{295}$ Despite this evidence, Judge Bernard Moore sentenced Pang to ten to twenty years of imprisonment, calling her behavior "outrageous" and stating, "[t]he message to society must be that we protect the sanctity of life."296 Moore may also have been swayed by the prosecutor's argument that Ms. Pang's claims of abuse were not credible because she did not "fit the typical profile of a battered woman whose life is often controlled by her abuser," since she worked outside of the home, drove a car, and had a boyfriend. $^{297}$

In contrast, Nancy Gulich had gone to battered women's shelters and sought medical care for the injuries inflicted upon her by her husband,

291. Pamela Lehman, Wife Gets State Prison in Killing, Morning Call (Allentown, Pa.), June 9,2005 , at B1.

292. Id.

293. Id.

294. Id.

295. Id.

296. Id.

297. Id. As Amy Busch notes, the perception of battered women as helpless is particularly problematic for battered women who kill, because they defy notions of who battered women are supposed to be by killing their abusers. BusCH, supra note 95, at 40. Juries who impose sentences dismiss claims of abuse not just in finding guilt, but also in sentencing. Olga Hernandez, whose children testified that she was beaten at least once a week for eighteen years, was sentenced by a jury to sixty years of imprisonment for the murder of her husband. John MacCormack, Wife Gets 60Year Term for Killing Her Spouse, SAN ANTONIO EXPRESS-NEwS, Jan. 18, 2005, at 2B. Hernandez acknowledged that she shot her husband and that she should be punished, but asked to stay out of prison so that she could be with her children. Id. When asked by the prosecutor, " "[i]f you are the victim, then what do you call him, Ms. Hernandez?,"” she replied, “'[a] victim, too."” Jesse Bogan, Widow Tells Jury of Spousal Abuse, SAN ANTONIO EXPRESS-NEWS, Jan. 15, 2005, at 3B. 
Paul Gulich, ${ }^{298}$ before she stabbed him in self-defense when he flew into a rage. ${ }^{299}$ Nancy was found guilty of third-degree murder and sentenced to ten to twenty years in prison-less than the maximum sentence of twenty to forty years, but a substantial jail term nonetheless for a fortytwo-year-old woman with no prior history of violence. ${ }^{300}$ During sentencing, the judge announced that while he had considered mitigating evidence-presumably, the violence she endured over time and the circumstances surrounding Paul Gulich's death-he "determined that punishment was necessary." ${ }^{, P 1}$

Battered women who kill "emphasize the circumstances of their actions, urging the criminal justice system to look at the violence they endured, at their inability to separate from their batterers, and at the lack of resources or solutions offered to them"-the context in which their crimes take place. ${ }^{302}$ Justice requires not only that judges hear evidence about this violence when sentencing battered women who kill, but that they also use that evidence to determine what a just desert would be. Like Dixie Shanahan, these women did not receive their just desertsnot because of judges whose discretion was fettered, but because of judges whose discretion went unused.

\section{The Myth of the Killing Spree}

Recall the words of the Des Moines Register columnist who urged that Dixie Shanahan serve a lengthy sentence: "Open a loophole for one woman to kill an abusive spouse and pretty soon you've got dozens of dead husbands." 303 Is there truth to this statement? Or does it reflect the unfounded fear that abused women everywhere will rise up to slay their abusive partners if given the chance?

In a number of cases, abused women who have killed their partners have been acquitted. ${ }^{304}$ The media have not reported an uptick in the

298. See Debbie Garlicki, Woman Gets 10-20 Years in '04 Killing, MoRnING CaLl (Allentown, Pa.), Feb. 2, 2006, at B1 (describing how Nancy's visits to shelters were well documented).

299. The jury "rejected Nancy Gulich's claim that she acted in self-defense." Id.

300. See id. (describing Nancy as a nonviolent person).

301. Id.

302. BusCH, supra note 95 , at 67.

303. See supra note 231 and accompanying text. Prosecutor Ron Johnson believed that this permission to kill would extend beyond just abusive partners. As he argued in State v. Hawthorne: "'You'll open the door to allow any woman to kill a man she doesn't like, and get away with it! ... It will be open season on killing men . . . !" WALKER, supra note 93, at 33; see also JONES, supra note 94, at 324 (quoting juror who feared that acquittal of battered woman who killed would lead to "open season on husbands in Atkinson County").

304. See, e.g., Alayna DeMartini, Woman Testifies in Civil Trial over Fatal Shooting of 
number of murders of abusive partners in those communities. Just as battered women are unlikely to be deterred from killing their abusive partners by the punishment that other women who kill receive, they are equally unlikely to kill their partners because other women are acquitted - or receive less than the maximum sentence. Battered women kill in very specific circumstances and for very specific reasons. They kill when their individual assessments of their own situations make them believe that they have no other choice but to kill or be killed. ${ }^{305}$ Luckily, relatively few battered women find themselves in situations that desperate. Compared to the number of women in the United States who are battered each year, the number of battered women who kill is very small. ${ }^{306}$

Look at trends in the homicide rates among intimate partners. Over the past thirty years, the number of women being killed by intimate partners has fallen by about $1 \%$ per year. ${ }^{307}$ Over that same period of time, however, the number of men being killed by their partners has declined by about $4 \%$ annually. ${ }^{308}$ Of the 1830 murders attributable to intimate partners in 1998 , women made up nearly $75 \%$ of the victims, an increase from just over $50 \%$ of all victims of intimate partner murder in $1976 .{ }^{309}$ The decline in the number of men being killed by their abused partners may be attributable to the greater availability of services and support for battered women. ${ }^{310}$ Improved services provide most battered

Husband, COlumBus DisPaTCH, Nov. 16, 2004, at B14 (describing the circumstances surrounding the acquittal of Kimberly Anderson); Eric Lenkowitz, Liberated Woman, N.Y. PosT, Apr. 20, 2004, at 23 (describing the case against and acquittal of Vanessa McCray); James L. Rosica, Jury: Actions Were Self-Defense, TAllahassee Democrat, June 3, 2005, at B1 (describing the acquittal of Anderia Belvis). Ann Jones argues that the media, by publicizing acquittals but failing to report on the more numerous cases where battered women were convicted of murdering their husbands, fed fears that men were being killed with impunity. JONES, supra note 94, at 291, 292. "Acquitted women ... were news precisely because they were the exception and not the rule; but reporting only acquittals left the reading public with the mistaken notion that women were 'getting off' with increasing frequency and were rarely if ever convicted of murder." Id. at 292. In fact, battered women are convicted of homicide at about the same rates as other defendants in homicide and serious felony trials - seventy-five to eighty percent. Maguigan, supra note 110, at 400 n.77.

305. See supra text accompanying notes $92-95$ (describing what drives women to kill their intimate partners).

306. In their analysis of the National Violence Against Women Survey, Patricia Tjaden and Nancy Thoennes estimated that 1.3 million women annually were assaulted by their partners. Patricia TJADEN \& NANCY ThoenNes, U.S. Dep'T OF Justice, Extent, NATURE, AND CONSEQUenCES OF INTIMATE PARTNer Violence 10 (2000). In contrast, 512 men were killed by their intimate partners in 1998. Callie Marie RenNison \& SARAH Welchans, U.S. DeP'T of Justice, INTIMATE PARTNER Violence 10 tbl.2 (2000).

307. RENNISON \& WelChANS, supra note 306, at 1.

308. Id

309. Id.

310. See supra note 234 (discussing the positive effects of the increase in resources). 
women with options other than killing a partner to escape an abusive relationship. The notion that battered women are simply waiting for a sign, in the form of reduced punishment, that it is socially acceptable to kill their abusers is ridiculous. But it is also possible that this widely held notion prevents judges from imposing just sentences on battered women who kill.

\section{CONCLUSION}

Some justification is required before punishing women like Dixie Shanahan-women who have been brutalized in uncountable ways and who perceive that they have no other alternative-for killing their abusers. Of the theories employed by legal philosophers, only retributivism, with its focus on individualized punishment that fits the crime committed and the offender who commits that crime, provides sufficient justification for punishing these women. But just deserts have been denied to Dixie Shanahan, Nancy Seaman, Kosal Pang, Nancy Gulich, and countless other battered women forced to make the terrible choice between their own lives and those of their abusers. Mandatory minimum sentences, judicial unwillingness to factor abuse in to punishment, and fears of widespread retaliation against abusive partners all contribute to the failure to sentence these women in ways commensurate with their crimes. And because they have not or cannot receive their just deserts, there is no justice for battered women who kill. 